Article

\title{
Effect of Using Aluminum Sulfate (Alum) as a Surface Amendment in Beef Cattle Feedlots on Ammonia and Sulfide Emissions
}

\author{
Mindy J. Spiehs * and Bryan Woodbury
}

check for updates

Citation: Spiehs, M.J.; Woodbury, B. Effect of Using Aluminum Sulfate

(Alum) as a Surface Amendment in Beef Cattle Feedlots on Ammonia and Sulfide Emissions. Sustainability 2022, 14, 1984. https://doi.org/ $10.3390 /$ su14041984

Academic Editor: Antonio Zuorro

Received: 30 December 2021

Accepted: 7 February 2022

Published: 10 February 2022

Publisher's Note: MDPI stays neutral with regard to jurisdictional claims in published maps and institutional affiliations.

Copyright: (C) 2022 by the authors. Licensee MDPI, Basel, Switzerland. This article is an open access article distributed under the terms and conditions of the Creative Commons Attribution (CC BY) license (https:// creativecommons.org/licenses/by/ $4.0 /)$.
USDA Meat Animal Research Center, Clay Center, NE 68933, USA; bryan.woodbury@usda.gov

* Correspondence: mindy.spiehs@usda.gov; Tel.: +1-402-762-4271

\begin{abstract}
The objective of this study was to measure $\mathrm{NH}_{3}$ from feedlot surface material (FSM) containing aluminum sulfate (alum). A 33-day lab-scale study was conducted using pans containing FSM and either $0,2.5,5$, or $10 \%$ alum. The $\mathrm{pH}$ of the FSM was significantly lower $(p<0.01)$ when treated with $2.5,5$, and $10 \%$ alum as opposed to the $0 \%$ alum treatment. $\mathrm{No} \mathrm{NH}_{3}$ volatilization occurred below a $\mathrm{pH}$ of 6.5 . A second study determined that small, weekly doses of $5 \%$ alum did not lower $\mathrm{NH}_{3}$ emissions further than a single dose of $5 \%$ alum. Two studies on the feedlot surface demonstrated a significant decrease $(p<0.01)$ in $\mathrm{pH}$ in the areas of the pens where alum was added compared to those that did not receive alum. Ammonia concentrations were lower $(p<0.05)$ for the areas that received alum compared to those that did not receive alum for 7 days when $5 \%$ alum was applied and 14 days when $10 \%$ alum was applied. In all the studies, sulfide emissions increased when alum was added to the FSM. We concluded $10 \%$ alum may reduce $\mathrm{NH}_{3}$ emissions from beef feedlots temporarily, but higher sulfide emissions offset this benefit.
\end{abstract}

Keywords: alum; aluminum sulfate; ammonia; beef; feedlot surface; hydrogen sulfide; sulfides; nutrients; manure

\section{Introduction}

Concentrated animal feeding operations (CAFOs) are intensely managed production systems to improve efficiency and allow for better care of the animals. This concentration can also have a deleterious impact on the environment. Cattle feedlot pen surfaces are especially problematic because the cattle manure is directly exposed to the environmental elements of rain, snow, sun, and wind. Feedlot surface material (FSM) is unlike any agricultural soil, consisting of a complex soil and manure mixture. Chemical, physical, and biological reactions that result in the release of a variety of compounds occur on the feedlot surface. Some reactions occur independently of one another, others are correlated. Typical airborne pollutants from CAFOs are comprised of particulate matter, biological materials, and chemicals including carbon dioxide $\left(\mathrm{CO}_{2}\right)$, methane $\left(\mathrm{CH}_{4}\right)$, nitrous oxide $\left(\mathrm{N}_{2} \mathrm{O}\right)$, ammonia $\left(\mathrm{NH}_{3}\right)$, hydrogen sulfide $\left(\mathrm{H}_{2} \mathrm{~S}\right)$ and other sulfides, alcohols, amides, aromatics, and volatile fatty acids [1-6]. Because of the complex reactions that occur on the feedlot surface, when the conditions change to prohibit the release of one gas, it can create an opportunistic environment for the production of a second gas, which further complicates the ability of producers to manage emissions from the feedlot surface.

Sulfide compounds are one emission of concern from feedlot operations. Hydrogen sulfide is a colorless gas that has a characteristic rotten egg smell. It is formed during bacterial decomposition of human and animal waste and is present in emissions from sewage treatment facilities and landfills. Hydrogen sulfide can be detected at very low concentrations (0.5-30 ppbv) and can begin to cause irritation to the lungs and nose at 25 ppmv [7]. Comparatively, other common odorants from livestock facilities such as $\mathrm{NH}_{3}$, phenol, and indole have odor detection thresholds of 5-53 ppm [8], 5900 ppb [9], and 
$140 \mathrm{ppb}$ [10], respectively. Five states in the United States, including Iowa, Minnesota, Nebraska, Rhode Island, and Texas, have ambient air quality standards for $\mathrm{H}_{2} \mathrm{~S}$ emissions from CAFOs [7]. Additionally, $\mathrm{H}_{2} \mathrm{~S}$ emissions from CAFOs are reportable to the USEPA when emissions exceed $45 \mathrm{~kg}$ (100 lbs) per day according to the Emergency Planning and Community Right-to-Know Act (EPCRA) guidelines. Over 168 compounds that contribute to odor nuisance from livestock facilities have been identified [11]. Of the 10 compounds with the lowest odor detection thresholds, $60 \%$ contained sulfur. Dimethyl disulfide (DMDS) and dimethyltrisulfide (DMTS) are products of the metabolism of sulfur-containing amino acids (methionine and cysteine) by Megasphaera anaerobic bacteria [1] and are two common odor-causing sulfide compounds from livestock manure. The odor threshold for DMDS is $0.16-12 \mathrm{ppb}[12,13]$, while DMTS has an odor threshold of $0.005-0.01 \mathrm{ppb}[14,15]$. These air quality standards and potential nuisance issues prompt the need for mitigation of $\mathrm{H}_{2} \mathrm{~S}$ and other sulfides from livestock facilities.

Ammonia emissions are commonly associated with livestock production. Utilization of nitrogen $(\mathrm{N})$ in cattle feed is inefficient, with only $10-30 \%$ of $\mathrm{N}$ consumed by cattle being utilized by the animal for growth, reproduction, milk production, and maintenance needs [16]. Consequently, the remaining $70-90 \%$ of consumed $\mathrm{N}$ is excreted in the urine and feces of the animal. The nutrients in livestock manure can be a valuable fertilizer for agricultural crops. Unfortunately, $\mathrm{N}$ losses as $\mathrm{NH}_{3}$ can be quite high from beef cattle feedlots. Upwards to $97 \%$ of urinary $\mathrm{N}$ is excreted as urea $[17,18]$, which is rapidly converted to $\mathrm{NH}_{3}$ [19] in a $\mathrm{pH}$ - and temperature-dependent reaction, with greater volatilization during the summer months compared to the winter months. Research has demonstrated that $51-73 \% \mathrm{~N}$ on the cattle feedlot surface can be lost as $\mathrm{NH}_{3}$ during the summer [20-23], and $35-50 \% \mathrm{~N}$ is lost during winter months [20-23]. A pH of 7 to 10 is ideal for $\mathrm{NH}_{3}$ volatilization [24], whereas a $\mathrm{pH} \leq 6.5$ will result in little $\mathrm{NH}_{3}$ volatilization [25]. Therefore, lowering the $\mathrm{pH}$ of the beef feedlot surface may reduce $\mathrm{N}$ volatilization and increase the fertilizer value of the manure which would be especially beneficial during the warm summer months.

Several strategies to reduce $\mathrm{NH}_{3}$, sulfides, and other odorous emissions from beef feedlot facilities, including the use of pen surface amendments, have been investigated. One pen surface amendment is urease inhibitors. Urease is an enzyme that converts urea to $\mathrm{NH}_{3}$. When this reaction is inhibited, $\mathrm{NH}_{3}$ emissions are reduced. When applied to FSM at a rate of 1-2 kg ha ${ }^{-1}, \mathrm{NH}_{3}$ emissions were $34.4-35.9 \%$ of the emissions of untreated FSM [26]. Other studies found that a urease inhibitor, combined with the plant essential oil thymol, retained $5.2 \mathrm{~g}$ of an initial $9.2 \mathrm{~g}$ of urea compared to only $1 \mathrm{~g}$ retained when the urease inhibitor was used alone [27], indicating less $\mathrm{NH}_{3}$ loss when the two products were used in combination. Another study examined the addition of corn oil, alum, urease inhibitors, alum, and potassium zeolite as surface amendments to lab-scale feedlot surfaces [28]. The addition of zeolite and fat decreased $\mathrm{NH}_{3}$ losses by 51 to $86 \%$ compared to no treatment.

The poultry industry has been successfully using aluminum sulfate (alum) to lower $\mathrm{NH}_{3}$ emissions for the past decade. Alum is applied at a rate of $5-10 \%$ of the weight of the litter and lowers the $\mathrm{pH}$ of the litter to bind $\mathrm{N}$ in the ammonium $\left(\mathrm{NH}_{4}\right)$ form and prevent volatilization. Ammonia fluxes from alum-treated litter are $70 \%$ lower than untreated litter $[29,30]$. The litter treated with alum has higher $\mathrm{N}$ content and a lower soluble phosphorus $(\mathrm{P})$ content, which results in less $\mathrm{P}$ leaching when alum-treated litter is land applied [31]. In a seven-year study, P losses in runoff were 340\% less when alum-amended litter was land applied to fescue than when untreated poultry litter was land applied [31], with no effect on P uptake by the fescue. When alum-treated poultry litter was land applied to corn fields in Virginia, little to no reduction in corn yields were detected, while $61-71 \%$ less dissolved reactive $P$ was recovered from runoff from fields that received alum-treated poultry litter compared to conventional poultry litter [32], indicating that the alum-treated litter was safe to use as a fertilizer. However, one concern with alum addition to livestock manure is the addition of sulfur to the system. Previous research has demonstrated that the addition of $10 \%$ alum to lab-scaled cattle bedpacks containing corn stover bedding lowered 
$\mathrm{NH}_{3}$ emission for up to 7 weeks but increased $\mathrm{H}_{2} \mathrm{~S}$ emission [33]. We hypothesized that adding alum to beef FSM would lower the $\mathrm{NH}_{3}$ emission and increase the $\mathrm{N}$ content in the manure but might also increase sulfide emissions from the FSM. Therefore, the objective of this study was to determine the effect of adding alum to feedlot surface material on $\mathrm{NH}_{3}$ and sulfide emissions.

\section{Materials and Methods}

Four studies were conducted to evaluate the use of alum as a feedlot surface amendment. The first two were conducted in a laboratory setting. The third and fourth were conducted on the feedlot surface of a pen that was recently vacated.

\subsection{Lab-Scale Studies}

The first lab-scale study was a titration study with four alum treatments evaluated: $0,2.5,5$, and $10 \%$ alum $\left(\mathrm{g} \mathrm{g}^{-1}\right)$ based on the mass of the FSM. Using methodology from previous studies in our lab [34,35], FSM was collected from three adjacent beef feedlot pens at the U.S. Meat Animal Research Center (USMARC) feedlot. Each pen was $30 \mathrm{~m} \times 90 \mathrm{~m}$ and contained a central mound constructed from manure and soil and a $3 \mathrm{~m}$ concrete apron located behind each feed bunk. One week prior to FSM collection, the livestock had been removed from the pen. Before that, approximately 80 steers were housed in each pen. The steers entered the pens at approximately $375 \mathrm{~kg}$ and were marketed at approximately $580 \mathrm{~kg}$, after being in the pen for 120 days. The FSM from the pens was scraped into a pile in each pen using a skid-steer front-end loader to skim across the top $15 \mathrm{~cm}\left(6^{\prime \prime}\right)$ of soil. From each pen, a $227 \mathrm{~L}$ (50 gallon) drum was filled with FSM and brought back to an enclosed garage, where plastic tarps were placed on the floor. All three drums were emptied onto the plastic tarps and thoroughly mixed using a shovel. The FSM was allowed to air-dry for three weeks before being ground in a portable woodchipper to ensure uniform mixture of the FSM. The resulting mixture served as the base FSM for the experiment. Nutrient composition of the initial FSM for the first and second experiments are found on Tables 1 and 2, respectively. The authors recognize that air-drying and mixing the manure in the woodchipper may have volatilized some initial $\mathrm{NH}_{3}$ from the FSM. However, this method allowed for the uniform dry-matter content of all pans, and large clots of FSM were not included in any pan, allowing all pans to have approximately the same chemical and physical characteristics at the start of the experiment. Once mixed, the FSM was added to stainless steel cafeteria-style pans $(50 \mathrm{~cm} \times 30 \mathrm{~cm} \times 6.5 \mathrm{~cm}$ : Figure $1 \mathrm{a}-\mathrm{c})$. There were six pans per treatment for a total of 24 pans. In each pan, $3 \mathrm{~kg}$ of FMS and $3 \mathrm{~kg}$ of water were added. Alum treatments were added in each pan, with the $2.5 \%$ alum treatment receiving $150 \mathrm{~g}$ of alum, the $5 \%$ alum receiving $300 \mathrm{~g}$ of alum, and the $10 \%$ alum treatment receiving $600 \mathrm{~g}$ of alum. The surface of the material was lightly raked using a garden weasel to simulate hoof traffic on the feedlot surface of a cattle pen. The total mass of each pan was recorded, and the pans were placed in an environmental chamber that was maintained at $30{ }^{\circ} \mathrm{C}$ and $60-65 \%$ humidity. Daily, the mass of the pans was recorded to determine how much water had evaporated. Water was added back to each pan to maintain the original pan mass which allowed for a uniform moisture content among all 24 pans of FSM [34,35]. Constant water content was maintained to represent an extended wet period that often occurs on feedlot pen surfaces [34,35]. On sampling days water was added to the pan $30 \mathrm{~min}$ prior to sampling. 
Table 1. Comparison of the nutrient composition of feedlot surface material (FSM) treated with aluminum sulfate (alum) and FSM prior to alum treatment.

\begin{tabular}{|c|c|c|c|c|c|c|}
\hline Nutrient & $\begin{array}{l}\text { Original } \\
\text { FSM }\end{array}$ & 0\% Alum & $2.5 \%$ Alum & $5 \%$ Alum & 10\% Alum & $p$-Value \\
\hline Dry matter, $\%$ & $88.4 \pm 0.9^{a}$ & $41.3 \pm 0.4^{\mathrm{c}}$ & $40.8 \pm 0.5^{c}$ & $42.3 \pm 1.0^{b c}$ & $44.0 \pm 0.7^{b}$ & $<0.01$ \\
\hline Total N, $\mathrm{g} \mathrm{kg}^{-1}$ & $23 \pm 0.3$ & $20.9 \pm 0.7$ & $20.4 \pm 0.6$ & $20.5 \pm 0.9$ & $22.6 \pm 0.7$ & 0.09 \\
\hline Organic-N, g kg -1 & $21.1 \pm 0.1$ & $20.5 \pm 0.6$ & $20.0 \pm 0.5$ & $19.7 \pm 0.9$ & $19.9 \pm 0.6$ & 0.77 \\
\hline Ammonium-N, $\mathrm{g} \mathrm{kg}^{-1}$ & $1.9 \pm 0.3^{b}$ & $0.2 \pm 0.1^{\mathrm{d}}$ & $0.3 \pm 0.1^{d}$ & $0.8 \pm 0.2^{\mathrm{c}}$ & $2.6 \pm 0.2^{a}$ & $<0.01$ \\
\hline Nitrate-N, $\mathrm{g} \mathrm{kg}^{-1}$ & $0.02 \pm 0.0^{b}$ & $0.17 \pm 0.1^{\mathrm{a}}$ & $0.08 \pm 0.0^{\mathrm{ab}}$ & $0.05 \pm 0.0^{b}$ & $0.00 \pm 0.0^{\mathrm{b}}$ & $<0.01$ \\
\hline Total $\mathrm{P}, \mathrm{g} \mathrm{kg}^{-1}$ & $13.2 \pm 0.1^{\mathrm{a}}$ & $13.5 \pm 0.1^{\mathrm{a}}$ & $12.4 \pm 0.1^{b}$ & $12.7 \pm 0.2^{b}$ & $12.5 \pm 0.1^{b}$ & $<0.01$ \\
\hline Total S, $\mathrm{g} \mathrm{kg}^{-1}$ & $6.1 \pm 0.2^{\mathrm{d}}$ & $6.9 \pm 0.1^{\mathrm{d}}$ & $17.3 \pm 0.7^{\mathrm{c}}$ & $22.4 \pm 0.3^{b}$ & $37.1 \pm 0.6^{\mathrm{a}}$ & $<0.01$ \\
\hline $\mathrm{pH}$ upper $2 \mathrm{~cm}$ & - & $8.3 \pm 0.0^{\mathrm{a}}$ & $6.4 \pm 0.1^{\mathrm{bB}}$ & $4.1 \pm 0.0^{\mathrm{cB}}$ & $3.9 \pm 0.0 \mathrm{cB}$ & $<0.01$ \\
\hline $\mathrm{pH}$ bottom $2 \mathrm{~cm}$ & - & $8.1 \pm 0.1^{a}$ & $7.3 \pm 0.1 \mathrm{bA}$ & $7.0 \pm 0.1^{\mathrm{cA}}$ & $6.6 \pm 0.2 \mathrm{dA}$ & $<0.01$ \\
\hline
\end{tabular}

All nutrient compositions, except dry matter content, are on a dry-matter basis. Different lowercase letters within a row indicate significant difference among treatments at $p<0.05$. $\mathrm{pH}$ values are from the upper $2 \mathrm{~cm}$ and bottom $2 \mathrm{~cm}$ of the stainless steel cafeteria pans filled with FSM and were taken on the last day of the study. Within a column, different uppercase letters indicate a significant difference between the upper and lower $\mathrm{pH}$ values for that treatment at $p<0.05$.

Table 2. Comparison of the nutrient composition of feedlot surface material (FSM) treated with 5\% aluminum sulfate (alum) in one dose (once), weekly doses of $20 \%$ of the total $5 \%$ alum over five weeks (weekly), and no treatment.

\begin{tabular}{|c|c|c|c|c|c|}
\hline Nutrient & $\begin{array}{l}\text { Original } \\
\text { FSM }\end{array}$ & 0\% Alum & $\begin{array}{l}5 \% \text { Alum } \\
\text { (Once) }\end{array}$ & $\begin{array}{l}5 \% \text { Alum } \\
\text { (Weekly) }\end{array}$ & $p$-Value \\
\hline Dry matter, \% & $85.4 \pm 1.0^{\mathrm{a}}$ & $36.5 \pm 0.2^{b}$ & $36.7 \pm 0.2^{b}$ & $36.6 \pm 0.2^{b}$ & $<0.01$ \\
\hline Total N, $\mathrm{g} \mathrm{kg}^{-1}$ & $24.1 \pm 0.4$ & $20.5 \pm 0.3$ & $21.6 \pm 0.9$ & $21.6 \pm 0.6$ & 0.37 \\
\hline Organic-N, $\mathrm{g} \mathrm{kg}^{-1}$ & $21.3 \pm 0.1$ & $19.3 \pm 0.3$ & $20.5 \pm 0.6$ & $20.2 \pm 0.5$ & 0.23 \\
\hline Ammonium-N, $\mathrm{g} \mathrm{kg}^{-1}$ & $1.3 \pm 0.3$ & $1.1 \pm 0.2$ & $1.1 \pm 0.3$ & $1.4 \pm 0.5$ & 0.76 \\
\hline Nitrate-N, $\mathrm{g} \mathrm{kg}^{-1}$ & $0.01 \pm 0.0$ & $0.0 \pm 0.0$ & $0.0 \pm 0.0$ & $0.00 \pm 0.0$ & - \\
\hline Total Phosphorus, $\mathrm{g} \mathrm{kg}^{-1}$ & $34.2 \pm 0.2$ & $34.8 \pm 0.7$ & $34.1 \pm 0.6$ & $33.4 \pm 0.4$ & 0.21 \\
\hline Total Sulfur, $\mathrm{g} \mathrm{kg}^{-1}$ & $17.1 \pm 0.1^{\mathrm{b}}$ & $17.8 \pm 0.5^{b}$ & $40.3 \pm 1.1^{\mathrm{a}}$ & $41.8 \pm 1.2^{\mathrm{a}}$ & $<0.01$ \\
\hline
\end{tabular}

All nutrient compositions, except dry matter content, are on a dry-matter basis. Nitrate- $\mathrm{N}$ was below detection limits for all FSM. Different letters within a row indicate significant difference among treatments at $p<0.05$.
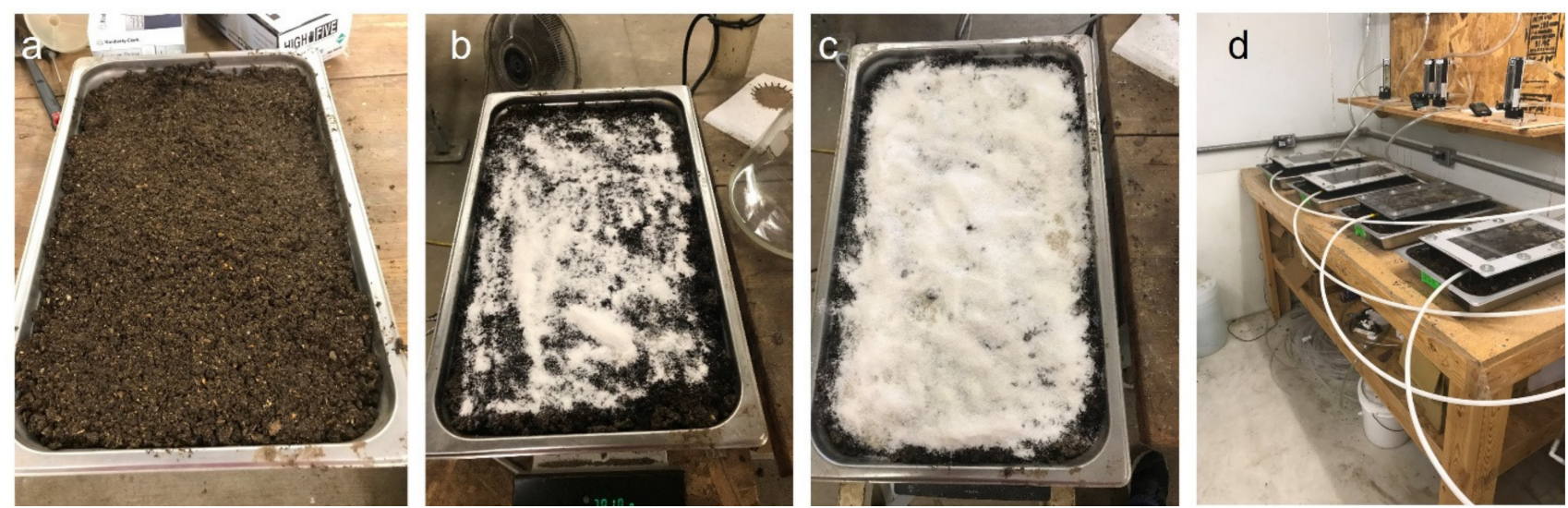

Figure 1. $(\mathbf{a}-\mathbf{c})$ : Stainless steel cafeteria pans with feedlot surface material (FSM) and varying amounts of aluminum sulfate (alum) added on the surface; (d): Wind tunnels on top of pans measuring gas emissions.

Air samples were collected on days $0,2,4,7,9,11,14,16,18,21,23,25$, and 28. Gases were measured using a small wind tunnel $(30.48 \mathrm{~cm} \times 15.24 \mathrm{~cm})$ [36]. On the collection days, background samples of the air in the environmental chamber were collected $30 \mathrm{~min}$ before the first sampling and were used to correct the gas concentrations collected during 
the sampling periods. After the background samples were collected, four pans were moved to the table in the environmental chamber, and a wind tunnel was placed on top of each pan ( $\mathrm{n}=4$; Figure $1 \mathrm{~d})$. While on the pans, the wind tunnel provided $1 \mathrm{~L} \mathrm{~min}^{-1}$ of air, and samples were collected from each pan for $18 \mathrm{~min}$. The first $8 \mathrm{~min}$ of sampling were used to achieve a steady-state, and the last $10 \mathrm{~min}$ were used for the data analysis. Air samples were analyzed directly from the wind tunnels. Inert tubing from the wind tunnel was attached to the gas sampling manifold which fed into the air sampling equipment. The gas sampling system was controlled by a 24-volt TECO Programmable Logic Relay (Model SG2-02OVR-D) which signaled multi-positional 3-way solenoids to open and close one of four air inlet lines on the gas sampling manifold. One line was opened at a time to allow for individual air sampling from each bedded pack. After completion of sampling for the first four pans, four more pans were placed on the table and the wind tunnels were placed on top of the pans. Pan rotation continued until all pans had been measured. Air sampling for $\mathrm{H}_{2} \mathrm{~S}$ used a Thermo Fisher 450i Hydrogen Sulfide/Sulfur Dioxide/Combined Sulfur Pulsed Fluorence gas analyzer (Thermo Fisher Scientist, Waltham, MA, USA). A Thermo Fisher 17i Ammonia Chemiluminescent gas analyzer was used to measure $\mathrm{NH}_{3}(\mathrm{Thermo}$ Fisher Scientist, Waltham, MA, USA).

A small sample of FSM (5-10 g) was collected from the top $2 \mathrm{~cm}$ of the FSM from each pan at each sampling date using a stainless steel microspatula with a mark on it to indicate $2 \mathrm{~cm}$. At the conclusion of the study, a sample was also collected from the bottom $2 \mathrm{~cm}$ of the pan to analyze $\mathrm{pH}$ below the surface. The $\mathrm{pH}$ was determined by mixing the FSM in a 2:1 ratio with distilled, deionized water and measuring using an IQ150 pH meter (Spectrum Technologies, Inc, Plainfield, IL, USA) calibrated with buffers at pH 4, 7, and 10. At the beginning and end of the study, samples of the FSM were collected and analyzed for total $\mathrm{N}$ [37], organic-N [37], nitrate-N [37], ammonium $\mathrm{N}$ [37], total P [38], and total sulfur [38]. Samples were sent to a commercial laboratory (Ward Laboratories, Kearney, NE, USA) for analysis.

Based on the results of the first lab-scale study, it was determined that $5 \%$ alum may be an ideal application rate for FSM. The second lab-scale study evaluated the frequency of application of the alum. Three treatments were evaluated: $0 \%$ alum and $5 \%$ alum applied as either a whole treatment on day 0 (5\%-once) or $20 \%$ of the total alum volume $(60 \mathrm{~g})$ applied on days $0,7,14,21$, and 28 (5\%-weekly). The 5\%-once treated pans received $300 \mathrm{~g}$ of alum on day 0 . As with the previous study, alum application was based on the mass of the FSM in the pans. The pans were constructed and maintained in the same manner as in the other lab-scale study. There were five experimental units per treatment. Sampling occurred on days $0,2,4,7,9,11,14,16,18,22,25,29$, and 32 and was conducted in the same way as the first lab-scale study.

\subsection{Field-Scale Studies}

The third and fourth studies were conducted on the feedlot surface. Six feedlot pens at the USMARC were utilized for each study. The third study used pens that had 20 animals per pen, and the fourth study used pens that had 30 animals per pen. Both types of pens had a central mound constructed on manure and soil and $3 \mathrm{~m}$ concrete apron by the feed bunk. Both set of pens had contained steers fed a corn-silage diet over a six-month period. One day before the study started, the cattle were removed. Three random locations in each pen were analyzed. Each location had a paired treatment with one area receiving alum and the other not receiving any alum application. In the first field-scale study, the treatments consisted of $0 \%$ alum $(n=18)$ and $5 \%$ alum $(n=18)$. In the second field-scale study the treatments were $0 \%$ alum $(n=18)$ and $10 \%$ alum $(n=18)$. The amount of alum added to the area was determined on a mass basis for a depth of $5 \mathrm{~cm}$ of FSM using the estimated density of feedlot surface material for Nebraska feedlots $\left(1.5 \mathrm{~g} \mathrm{~cm}^{-3}\right)$ [39], which was within the range of other published data [40]. At each treatment location, a circular anchor made from PVC that was $30.48 \mathrm{~cm}$ in diameter was inserted into the ground [41] (Figure 2). This anchor was used for the air sampling equipment, and the $\mathrm{pH}$ was collected 
from inside the anchor area. Samples were collected on days $0,3,7,10,14,17,21$, and 24 . Temperature and moisture content of each sampling location was recorded at the time of data collection.
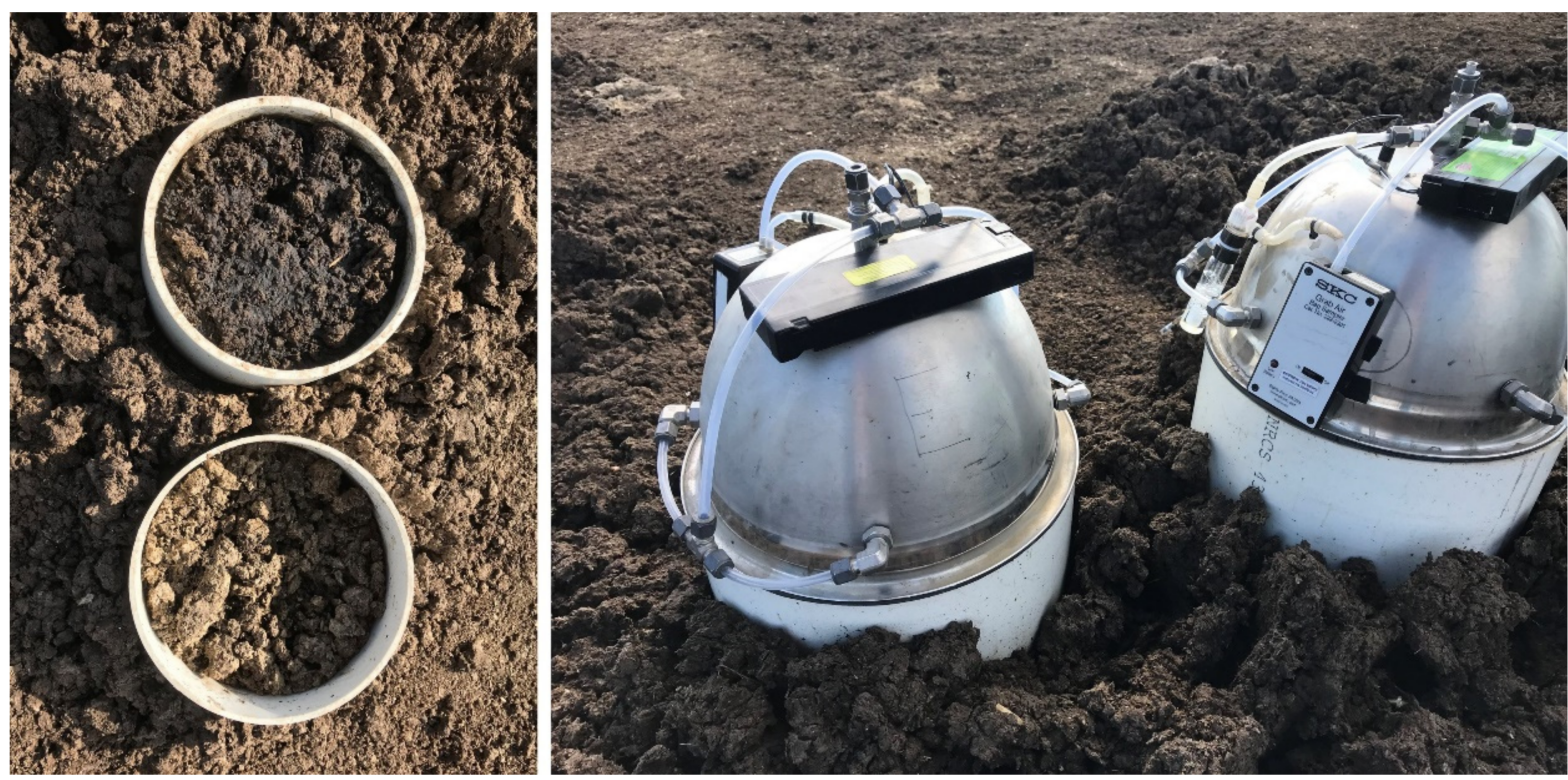

Figure 2. On the left are side-by-side paired test locations on the feedlot surface with PVC anchors. On the right are the stainless steel flux chambers equipped with the acid traps to measure $\mathrm{NH}_{3}$ emission.

Approximately $18-20 \mathrm{~h}$ prior to gas sampling, $1 \mathrm{~L}$ of water was added to the soil inside the PVC anchors at each treatment location to determine emissions in a prolonged wet period, which often happens to areas of feedlot pens. Ammonia flux was determined by collecting air samples from the pen surface using stainless steel hemispherical flux chambers $[42,43]$ with acid traps containing $0.5 \mathrm{~N}$ sulfuric acid. The chamber head volumes were recycled through the acid traps for $20 \mathrm{~min}$ [43]. The $\mathrm{NH}_{3}$ content in the acid traps was analyzed using a modification of the Sigma urea N kit (Procedure No. 640, SigmaAldrich Chemicals, St. Louis, MO, USA). Five microliters of each standard and sample were transferred to a well in a 96-well microtiter plate. This was followed by additions of $50 \mu \mathrm{L}$ phenol nitroprusside, $50 \mu \mathrm{L}$ alkaline hypochlorite, and $250 \mu \mathrm{L}$ distilled water. Color was allowed to develop for $20 \mathrm{~min}$ at room temperature. Absorbance at $620 \mathrm{~nm}$ was measured using a Bio-Tek Ceres UV900C microplate reader. The concentration of each 96-well plate was determined from a standard curve run with the plate. The coefficient of variation of each duplicate sample in the plate was less than 3\%. At each sampling location, 5-10 g of soil was collected in $50 \mathrm{~mL}$ plastic conical containers and diluted 2:1 with distilled water to determine the $\mathrm{pH}$ of the soil using an IQ150 $\mathrm{pH}$ meter (Spectrum Technologies, Inc, Plainfield, IL, USA), calibrated with buffers 4, 7, and 10.

To determine sulfur emissions from the feedlot surface, VOC sample collection was completed using stainless steel sorbent tubes connected to an inlet port on the stainless steel hemispherical flux chamber using flexible plastic tubing. The preconditioned stainless steel sorbent tubes $(89 \mathrm{~mm} \times 6.4 \mathrm{~mm} \mathrm{OD})$ were filled with Tenax TA sorbent (Markes International, Inc., Wilmington, DE, USA) and brass polytetrafluorethylene (PTFE) ferrules storage caps [44]. Headspace air sample was pulled through the sorbent tubes at a flow rate of $75 \mathrm{~mL} \mathrm{~min}^{-1}$ for $20 \mathrm{~min}$ for a sample volume of $1.5 \mathrm{~L}$ using a vacuum pump (Pocket Pump 210 Series, SKC Inc., Eighty Four, PA, USA) [44,45]. Sorbent tubes were analyzed for dimethyl disulfide (DMDS), and dimethyl trisulfide (DMTS) using a thermal desorption-gas chromatography-mass spectrometry system $[45,46]$. The TD system was a Markes Unity 2 (Markes International Inc., Wilmington, DE, USA) with autosampler (Ultra 2, Markes International, Inc., Wilmington, DE, USA) coupled to an Agilent GCMS (7890A/5975C, Agilent Technologies, Inc., Santa Clara, CA, USA) [46]. Samples of the FSM were collected 
before application of the treatments and at the end of each study. Unfortunately, the samples collected from the first field-scale study were compromised during storage prior to analysis. Samples were sent to a commercial laboratory (Ward Laboratories, Kearney, $\mathrm{NE}$, USA) and analyzed for analyzed for total $\mathrm{N}$, organic- $\mathrm{N}$, nitrate- $\mathrm{N}$, ammonium $\mathrm{N}$, and total sulfur $[37,38]$.

\subsection{Statistical Analysis}

Data in the first study were analyzed as a completely randomized design with repeated measures using the MIXED Procedure of SAS [47]. The model included the effects of alum concentration, time, and the interaction. The experimental unit was the pan. The second lab-scale study was analyzed as a completely randomized design with repeated measures using the MIXED Procedure of SAS. The model included the effects of treatment, time, and the interaction. The field-scale studies were analyzed as randomized compete block designs with repeated measures using the MIXED procedure of SAS. The model included the effect of block (pen), alum concentration, time, and the interactions. The area inside the PVC ring was the experimental unit. Covariate structure was modeled to get the lowest Akaike information criteria (AIC) value. Several structures were tested, and the compound symmetry covariate structure provided the lowest AIC value. When significant differences were detected, Fisher's least significant difference tests were used to determine significant differences among treatments. All differences were considered significant at $p<0.05$.

\section{Results}

\subsection{Titration Study}

The $\mathrm{pH}$ of the common FSM that was used in all pans was 8.3. Immediately after adding the alum, there was a significant reduction in $\mathrm{pH}$ for all FSM with alum compared to the control pans that did not have any alum applied (Figure 3a). The pH of the FSM in the pan with no alum remained higher than all FSM treated with alum throughout the study. Starting on day 9 , the FSM that received $2.5 \%$ alum had a significantly higher $\mathrm{pH}$ than the FSM that was treated with 5 or $10 \%$ alum. The $\mathrm{pH}$ of the FSM treated with 5 or $10 \%$ alum did not differ from one another throughout the entire study. Average $\mathrm{pH}$ for each treatment for the entire 28-day study was $8.05,5.28,4.38$, and 4.18 for the $0,2.5,5$, and $10 \%$ alum treatments, respectively. Other researchers [26] were also able to successfully lower the $\mathrm{pH}$ of cattle FSM in a lab-scale situation for up to 21 days when alum was added at a rate of $4500 \mathrm{~kg} \mathrm{ha}^{-1}$ or $9000 \mathrm{~kg} \mathrm{ha}^{-1}$. Average $\mathrm{pH}$ for the 21 -day study was 5.98 and 4.20 , respectively for the 4500 and $9000 \mathrm{~kg} \mathrm{ha}^{-1}$ treatments. Conversely, when alum was added to lab-scale cattle bedded manure packs, an addition of $5 \%$ alum was only able to significantly lower the $\mathrm{pH}$ compared to untreated cattle bedded manure packs for seven days, while a $10 \%$ addition of alum successfully lowered $\mathrm{pH}$ for 14 days [33]. This may be due to differences in organic matter, dry-matter, or buffering capacity of the different substances that were treated with the alum.

Interestingly, when $\mathrm{pH}$ measurements were taken from the bottom $2 \mathrm{~cm}$ of the stainless steel pans, the $\mathrm{pH}$ measurements were significantly higher than on the top $2 \mathrm{~cm}$ of the FSM (Table 1). Even with daily water additions and slight raking of the FSM each day, the alum did not penetrate much beyond the surface layer. Cattle walking on the surface of a feedlot may incorporate the alum deeper into the soil profile, creating a different result if animals were present.

Due to the low $\mathrm{pH}$ in the FSM that was treated with alum, $\mathrm{NH}_{3}$ flux was significantly lower when $2.5,5$, or $10 \%$ alum was added compared to the feedlot surface material that contained no alum (Figure $3 \mathrm{~b}$ ). There was a significantly higher concentration of $\mathrm{NH}_{3}$ at days 0 , 2, and 4 for the FSM without alum compared to those treated with alum. However, as no new $\mathrm{N}$ sources were being added to the FSM, the available $\mathrm{N}$ in the FSM was quickly depleted by the microbes, resulting in essentially no $\mathrm{NH}_{3}$ emissions after day 7 of the study. Similar to this study, previous research has demonstrated virtually no $\mathrm{NH}_{3}$ emissions for up to 21 days when alum was applied to beef FSM [26]. 
a. $\mathrm{pH}$ of feedlot surface material over time
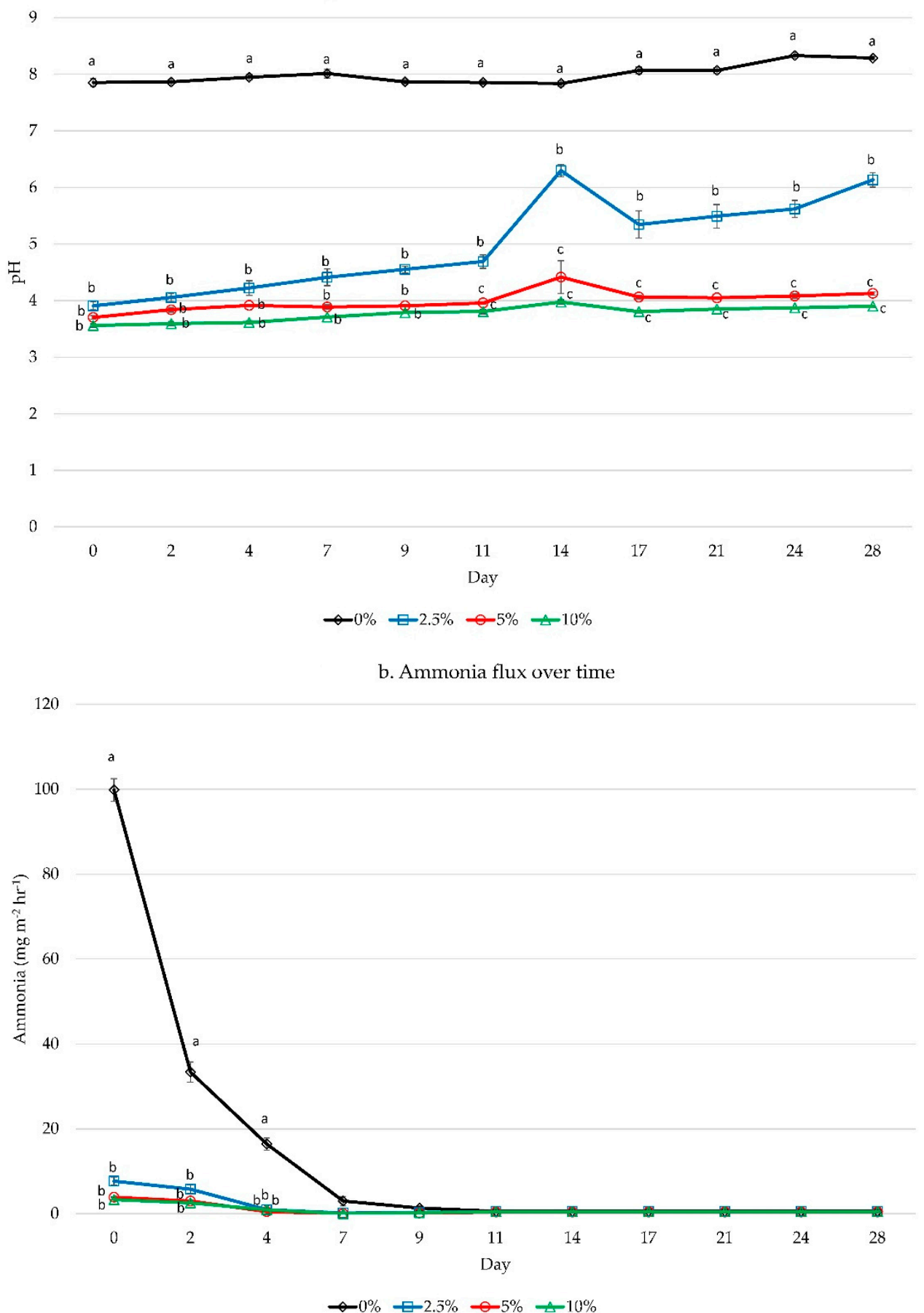

Figure 3. Cont. 


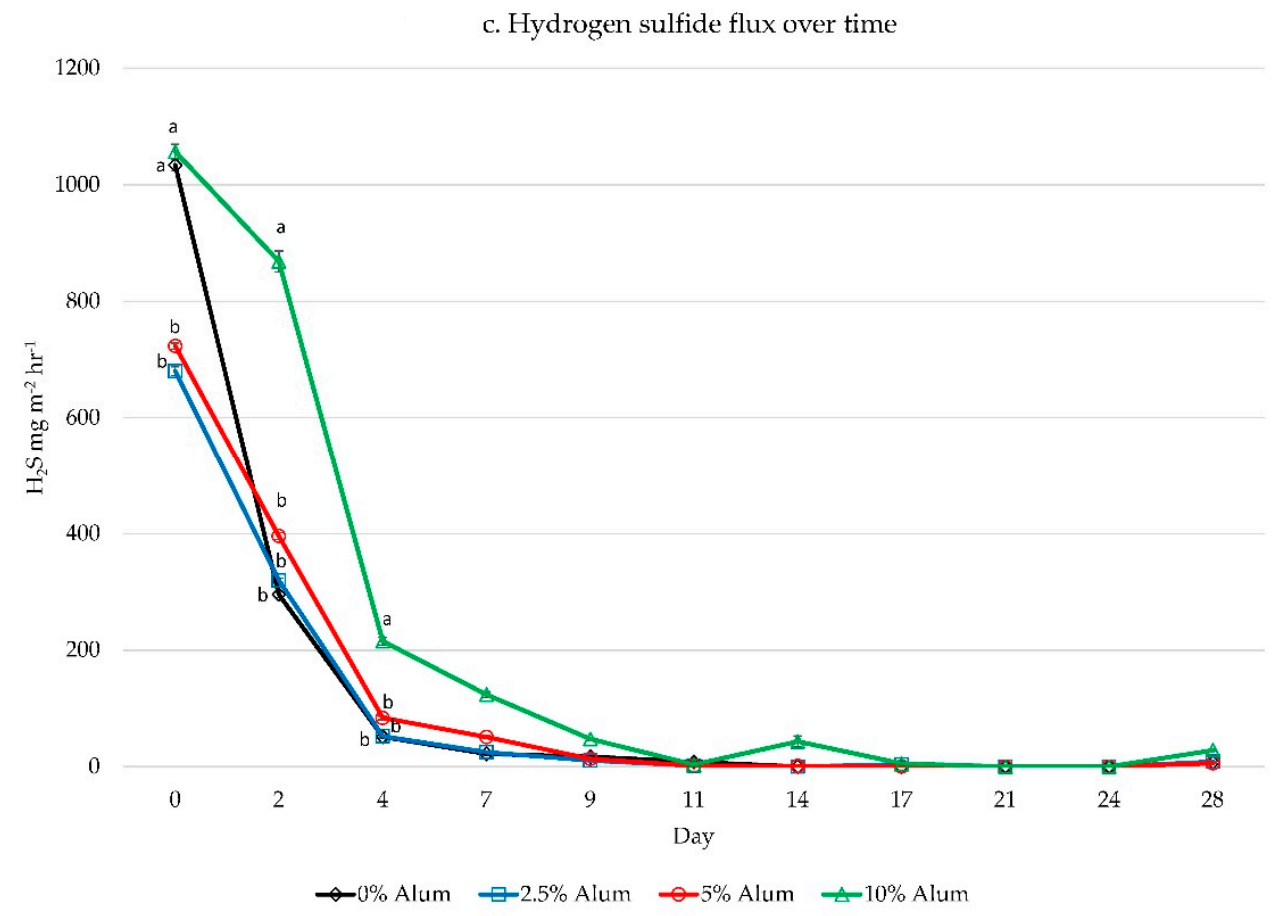

Figure 3. (a) The $\mathrm{pH}$ of feedlot surface material (FSM) in lab-scaled stainless steel pans treated with $0 \%\left(\mathrm{~g} \mathrm{~g}^{-1}\right)$ aluminum sulfate (alum) had significantly higher $\mathrm{pH}$ than FSM treated with $2.5,5$, or $10 \%$ alum (b) Ammonia flux ( $\mathrm{mg} \mathrm{m}^{-2} \mathrm{hr}^{-1}$ ) of feedlot surface material (FSM) treated 2.5, 5, and 10\% aluminum sulfate (alum) was lower than $\mathrm{NH}_{3}$ flux from untreated FSM. (c) Hydrogen sulfide $\left(\mathrm{H}_{2} \mathrm{~S}\right.$ ) flux $\left(\mathrm{mg} \mathrm{m}^{-2} \mathrm{hr}^{-1}\right)$ was greater for the untreated feedlot surface material (FSM) and FSM treated with $10 \%$ alum on day 1 . On days 2 and 4 , FSM treated with $10 \%$ alum had significantly greater $\mathrm{H}_{2} \mathrm{~S}$ flux than FSM with any other treatment. For all graphs, different letters indicate significant differences $(p<0.05)$ between the treatments at the time point.

Overall average $\mathrm{H}_{2} \mathrm{~S}$ flux was significantly greater for FSM treated with $10 \%$ alum $\left(274.3 \mathrm{mg} \mathrm{m}^{-2} \mathrm{hr}^{-1}\right)$ compared to FSM treated with $0,2.5$, or $5 \%$ alum $(179.4,150.2$, and $163.0 \mathrm{mg} \mathrm{m}^{-2} \mathrm{hr}^{-1}$, respectively). Hydrogen sulfide flux was different for the various alum treatments at three points during the study. At the beginning of the study, the FSM with $0 \%$ alum and the FSM that contained $10 \%$ alum had similar $\mathrm{H}_{2} \mathrm{~S}$ flux, which were significantly higher than the concentrations of $\mathrm{H}_{2} \mathrm{~S}$ from FSM that was treated with either 2.5 or $5 \%$ alum. On days 2 and 4, the FSM that contained $10 \%$ alum continued to have a higher concentration of $\mathrm{H}_{2} \mathrm{~S}$ compared to all other feedlot surface material. While it was unclear why the FSM with $0 \%$ alum had such a high flux of $\mathrm{H}_{2} \mathrm{~S}$ initially, it is likely that the FSM treated with $10 \%$ alum had significantly higher $\mathrm{H}_{2} \mathrm{~S}$ flux at the beginning of the study due to the sulfur contained in the aluminum sulfate (alum) added to the FSM. Other research [48] also reported an increase in $\mathrm{H}_{2} \mathrm{~S}$ odor when alum was added to swine manure because sulfate is commonly used by anaerobic bacteria in liquid animal waste for decomposition of organic compounds [49]. The drop in $\mathrm{H}_{2} \mathrm{~S}$ flux at day 7 is likely due to depletion of the sulfur substrate.

Nutrient composition of the FSM after 28 days was significantly different due to alum treatment (Table 1). There was a tendency for pans treated with $10 \%$ alum to have higher total $\mathrm{N}$, but this difference was not significant $(p=0.09)$. Feedlot surface material treated with $10 \%$ alum had significantly higher ammonium-N concentration compared to any treatment. There was a linear decrease in the ammonium-N concentration in the FSM as the concentration of alum increased. Nitrate was significantly lower in FSM that received no alum treatment compared to the FSM that received any concentration of alum. Total sulfur increased linearly with increasing concentration of alum added to the FSM. These results were consistent with what was expected and are supported by previous research. Other 
researchers also [50] reported significantly higher concentrations of total $\mathrm{N}$ as the alum concentration in poultry litter increased from 100 to $300 \mathrm{~g}$ of liquid aluminum chloride per $\mathrm{kg}$ of poultry litter. Organic $\mathrm{N}$ was unaffected by alum treatment and inorganic $\mathrm{N}$ (which includes nitrate and ammonium) was significantly higher in poultry litter that received 100-300 g of liquid alum per kg of poultry litter compared to poultry litter that was not treated with alum [50]. Likewise, others [26] reported significantly higher nitrogen content in soil treated with alum compared to soil only or to a soil/manure mixture. Sulfur content was also higher when alum was used in that study [26], due to the sulfur contained in alum. However, this may contribute to the production of $\mathrm{H}_{2} \mathrm{~S}$ and other odorous sulfide compounds generated in livestock waste.

Based on the results of the initial lab-scale study, it was determined that all three concentrations of alum successfully lowered $\mathrm{NH}_{3}$ flux. Ammonium nitrate was significantly higher in the FMS treated with 5 or $10 \%$ alum compared to untreated FSM or FSM treated with $2.5 \%$ alum, which would increase the fertilizer value of the FSM. However, due to the significant increase in $\mathrm{H}_{2} \mathrm{~S}$ flux from the FSM treated with $10 \%$ alum, it was determined that $5 \%$ alum may be the best treatment for FSM.

\subsection{Dose Frequency Study}

The addition of $5 \%$ alum to the FSM significantly lowered the $\mathrm{pH}$ of the FSM (Figure $4 \mathrm{a}$ ) for up to 14 days. Initially, FSM that received a single dose of alum had a significantly lower $\mathrm{pH}$ than the FSM that received $20 \%$ of the total alum dose in weekly increments. At day 7 , the $\mathrm{pH}$ of the FSM that was treated with the weekly alum dose was lower than the $\mathrm{pH}$ of the FSM treated with a single alum dose, but this reduction was not sustained. From day 9 until the end of the 32-day study, FSM treated with both alum treatments had similar pH. This was a substantially different result than was observed in the titration study. We expected the $5 \%$ treatment applied all in one dose to behave similarly to the $5 \%$ treatment in the titration study, significantly lowering the $\mathrm{pH}$ of the FSM for the duration of the study. While we are unsure why this occurred, it may have been due to the different FSM that was used in the second study compared to the first study. Many factors affect the ability of soil to buffer a $\mathrm{pH}$ change, including clay, organic matter content, cation-exchange capacity, carbonate, bicarbonate, organic acid content, and phosphate content, which were not measured in this study. Additional studies need to examine these properties to determine the ability of alum to effectively lower and sustain a lowered $\mathrm{pH}$ in various FSM.

Ammonia flux was significantly lower when $5 \%$ alum was added to the FSM on days 0 and 2 (Figure $4 \mathrm{~b}$ ). Adding $20 \%$ of the total alum treatment in five equal weekly increments initially lowered the $\mathrm{NH}_{3}$ flux compared to untreated FSM but was not able to maintain the same level of reduction in $\mathrm{NH}_{3}$ emission as a one-time dose of $5 \%$ alum did until day 7 . At that time, the overall $\mathrm{NH}_{3}$ emission was lowered, due to the depletion of $\mathrm{N}$ substrate in the pan, making it impossible to know if the addition of alum would have been able to successfully lower $\mathrm{NH}_{3}$ emission past day 7 , even though the addition of alum to the FSM was able to maintain a significant reduction in $\mathrm{pH}$ throughout most of the 32-day study.

The nutrient composition of FSM from the untreated FSM and the FSM treated with either frequency of alum application was not statistically different for any nutrient except sulfur. Ammonium accounts for a very small portion of the overall $\mathrm{N}$ profile and nitrate-N was not at detectable levels in the FSM at the end of the study. Sulfur was significantly higher in both alum treatments compared to the untreated FSM, but there was no statistical different between the sulfur content of either alum treatment (Table 2). This was consistent with the previous lab-scaled study and other research [26] where sulfur nutrient content increased as alum was added to the FSM. The extra sulfur in the FSM with the alum treatments did not appear to affect $\mathrm{H}_{2} \mathrm{~S}$ flux; there was no statistical difference $(p=0.79)$ in $\mathrm{H}_{2} \mathrm{~S}$ flux among the untreated FSM $\left(76 \pm 6.7 \mathrm{mg} \mathrm{m}^{-2} \mathrm{hr}^{-1}\right), 5 \%$ weekly $\left(91.6 \pm 6.7 \mathrm{mg} \mathrm{m}^{-2} \mathrm{hr}^{-1}\right)$, and $5 \%$ once $\left(51 \pm 4.7 \mathrm{mg} \mathrm{m}^{-2} \mathrm{hr}^{-1}\right)$ treatments. There appeared to be little benefit of adding the $5 \%$ alum dose in $20 \%$ weekly increments. 
a. $\mathrm{pH}$ of feedlot surface material over time

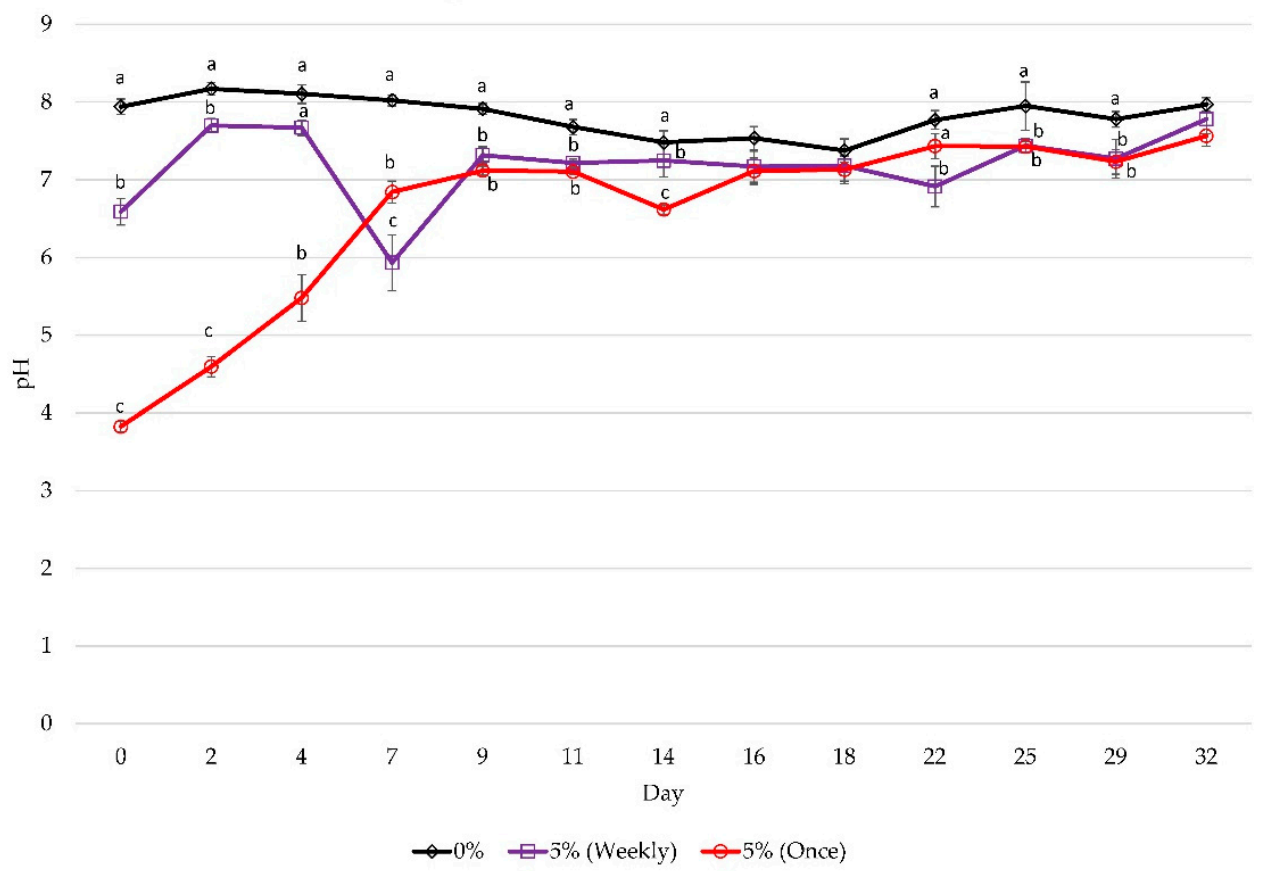

b. Ammonia flux over time

80

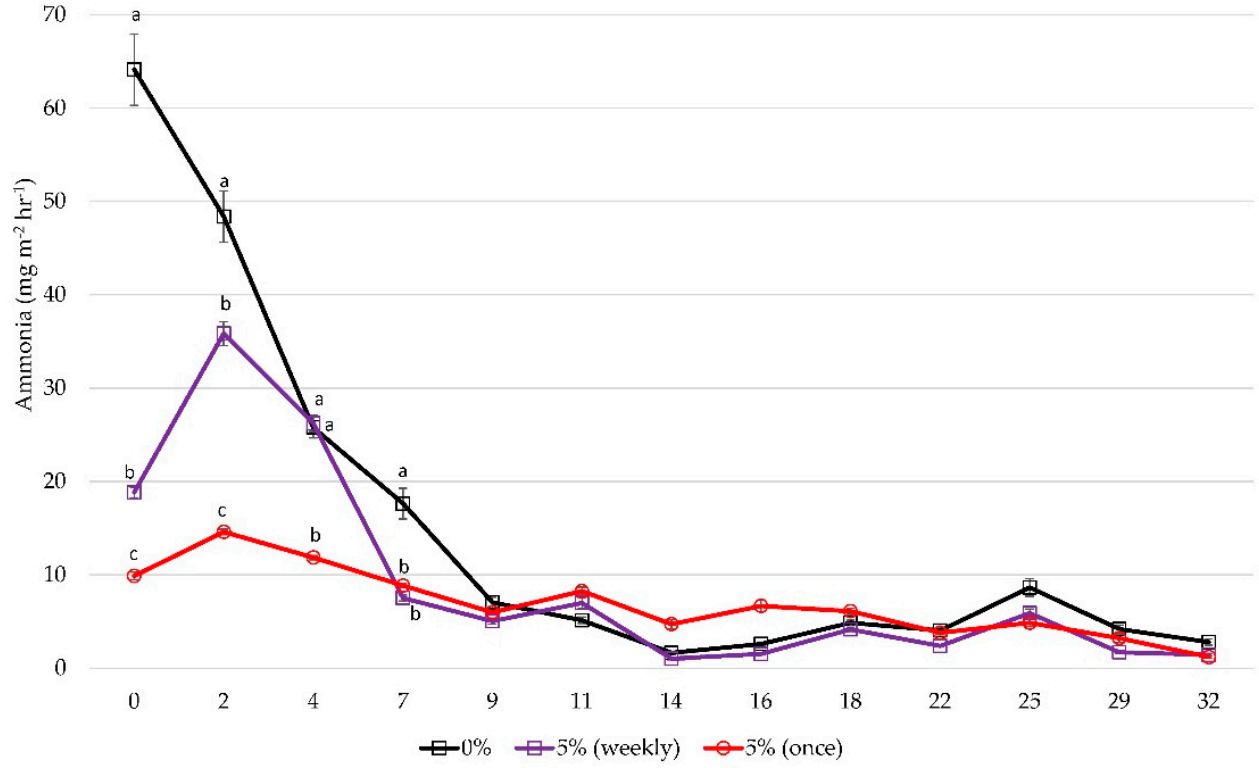

Figure 4. (a) In general, the $\mathrm{pH}$ of the feedlot surface material (FSM) treated with $5 \%$ alum was lower than the FSM receiving no alum treatment. Adding 20\% of the total alum treatment at five weekly intervals did not appear to suppress $\mathrm{pH}$ for any longer than a single dose of 5\% alum. (b) Ammonia flux $\left(\mathrm{mg} \mathrm{m}^{-2} \mathrm{hr}^{-1}\right)$ of feedlot surface material (FSM) treated $5 \%$ aluminum sulfate (alum) was generally lower than untreated FSM for up to 7 days. For both graphs, different letters indicate significant differences between the treatments at the time point.

\subsection{Feedlot Surface Studies}

Based on the results of the lab-scale study, it was determined that there was little advantage to adding $10 \%$ alum compared to $5 \%$ alum as both significantly reduced $\mathrm{NH}_{3}$ flux compared to FSM not treated with alum, and $\mathrm{H}_{2} \mathrm{~S}$ emission increased with an increasing 
dose of alum. Therefore, the lowest effective dose was selected for use in the feedlot surface studies, which was the 5\% alum. Additionally, it did not appear that 5\% alum applied in incremental additions on a weekly basis would be effective in lowering $\mathrm{NH}_{3}$ from the feedlot surface material, so the alum was added in one dose at the initiation of the feedlot surface study.

Average ambient temperatures from 9:00 AM-4:00 PM and average soil temperature and moisture content for each treatment on each sampling date is also shown in Table 3. There was no precipitation on any data collection day. There were no significant differences in soil temperature or soil moisture content between treatments, or any treatment by day interactions. There were significant differences in soil temperature and moisture between days due to differences in ambient temperature and precipitation events.

Table 3. Ambient temperature range between $9 \mathrm{AM}$ and $4 \mathrm{PM}$, soil temperature and moisture content on day of data collection for Experiment 3 and 4.

\begin{tabular}{cccc}
\hline & $\begin{array}{c}\text { Ambient Temp } \\
\text { Range, }{ }^{\circ} \mathbf{C}\end{array}$ & $\begin{array}{c}\text { Average Soil } \\
\text { Temp, }{ }^{\circ} \mathbf{C}\end{array}$ & $\begin{array}{c}\text { Average Soil } \\
\text { Moisture, } \%\end{array}$ \\
\hline $\begin{array}{c}\text { Experiment 3, Day } \\
0\end{array}$ & $20.6-25.6$ & $23.1 \pm 0.2 \mathrm{~b}$ & $49.9 \pm 2.3 \mathrm{xy}$ \\
3 & $20.0-25.0$ & $22.8 \pm 0.1 \mathrm{c}$ & $52.3 \pm 2.4 \mathrm{xy}$ \\
7 & $21.7-30.6$ & $24.7 \pm 0.1 \mathrm{a}$ & $52.0 \pm 1.5 \mathrm{xy}$ \\
10 & $23.3-30.6$ & $22.5 \pm 0.2 \mathrm{c}$ & $55.0 \pm 1.4 \mathrm{x}$ \\
14 & $18.9-25.0$ & $22.5 \pm 0.1 \mathrm{c}$ & $48.1 \pm 1.8 \mathrm{y}$ \\
17 & $23.3-28.3$ & $21.9 \pm 0.1 \mathrm{~d}$ & $49.4 \pm 1.3 \mathrm{y}$ \\
21 & $20.0-25.6$ & $21.6 \pm 0.1 \mathrm{e}$ & $36.2 \pm 2.2 \mathrm{z}$ \\
24 & $18.9-22.8$ & $21.8 \pm 0.1 \mathrm{~d}$ & $51.0 \pm 1.1 \mathrm{y}$ \\
0 & & & \\
3 & $28.9-32.2$ & $27.7 \pm 0.3 \mathrm{xy}$ & $65.7 \pm 2.4 \mathrm{~b}$ \\
7 & $21.7-27.8$ & $29.4 \pm 0.3 \mathrm{xy}$ & $59.3 \pm 3.5 \mathrm{~b}$ \\
10 & $21.1-26.7$ & $29.1 \pm 0.3 \mathrm{xy}$ & $63.1 \pm 3.8 \mathrm{~b}$ \\
14 & $23.9-28.3$ & $28.5 \pm 0.2 \mathrm{xy}$ & $68.3 \pm 2.3 \mathrm{~b}$ \\
17 & $23.3-27.8$ & $33.0 \pm 6.3 \mathrm{x}$ & $66.3 \pm 0.1 \mathrm{~b}$ \\
21 & $20.6-25.0$ & $25.1 \pm 0.2 \mathrm{y}$ & $80.6 \pm 1.3 \mathrm{a}$ \\
24 & $20.0-26.7$ & $20.8 \pm 0.1 \mathrm{z}$ & $80.0 \pm 0.1 \mathrm{a}$ \\
Experiment 4, Day & $25.6-31.7$ & $24.6 \pm 0.1 \mathrm{y}$ & $66.4 \pm 2.7 \mathrm{~b}$ \\
Statistical Analysis & & & \\
Treatment & - & 0.23 & 0.79 \\
Day & - & 0.91 & $<0.01$ \\
Treatment x Day & - & 0.89 & 0.98 \\
\hline
\end{tabular}

Average soil temperature and average soil moisture are means with standard errors. Experiment 3 was field-scale study using 0 and $5 \%$ alum treatments. Experiment 4 was field-scale study using 0 and $10 \%$ alum treatments. Different letters within a column and experiment indicate significant differences at $p<0.05$.

The $\mathrm{pH}$ of the feedlot surface at the 18 locations not treated with alum ranged from 7.9 to 8.5 with an average $\mathrm{pH}$ of 8.2 , while the $\mathrm{pH}$ of the feedlot surface at the 18 locations treated with $5 \%$ alum ranged from 4.9 to 7.0 , with an overall average $\mathrm{pH}$ of 6.3 . An application of $5 \%$ alum to the feedlot surface significantly lowered the $\mathrm{pH}$ of the feedlot surface for the entire 24 days of the study compared to locations in the pen that did not receive an alum treatment (Figure 5a). This reduction in $\mathrm{pH}$ did reduce $\mathrm{NH}_{3}$ flux from the feedlot surface $\left(p=0.05\right.$ ) for a period of time (Figure $5 \mathrm{~b}$ ). Initially $\mathrm{NH}_{3}$ emissions were reduced, but once the $\mathrm{pH}$ of the feedlot surface reached 6.5 on day 10 , the $\mathrm{NH}_{3}$ emissions from the feedlot surface treated with $5 \%$ alum began to emit $\mathrm{NH}_{3}$, causing a significantly higher $\mathrm{NH}_{3}$ flux on day 10 for locations treated with 5\% alum compared to locations that received no alum treatment. The $\mathrm{NH}_{3}$ flux followed a similar pattern for both the treated and untreated feedlot surfaces, with just a slight shift in the peak flux from day 7 to day 10 . Over the course of the 24 days, average $\mathrm{NH}_{3}$ flux did not differ between the untreated and treated feedlot surface areas. Since there were no new N sources being added to the surface, $\mathrm{NH}_{3}$ emissions began to decline significantly over the 24-day period. 
a. $\mathrm{pH}$ of feedlot surface over time

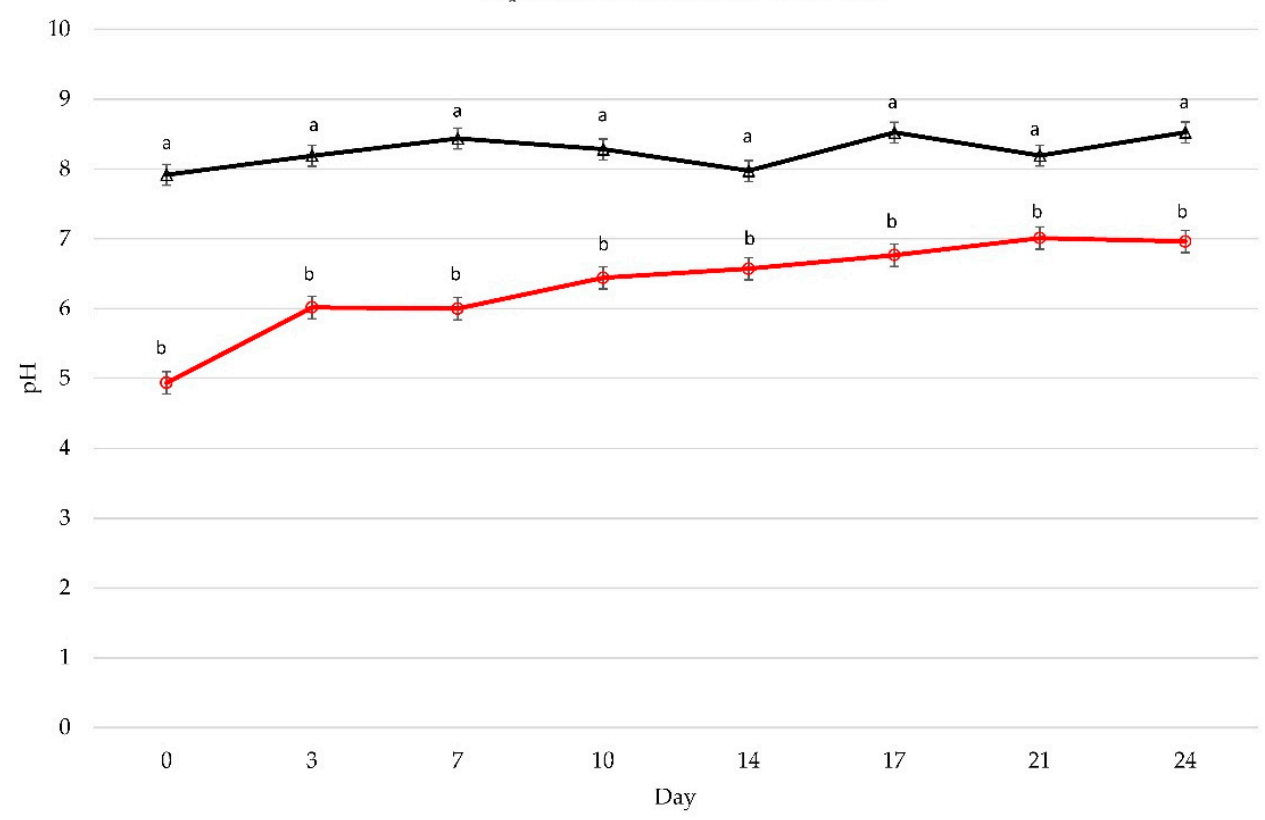

$\leftarrow 0 \%$ Alum $-5 \%$ Alum

60

b. Ammonia flux over time

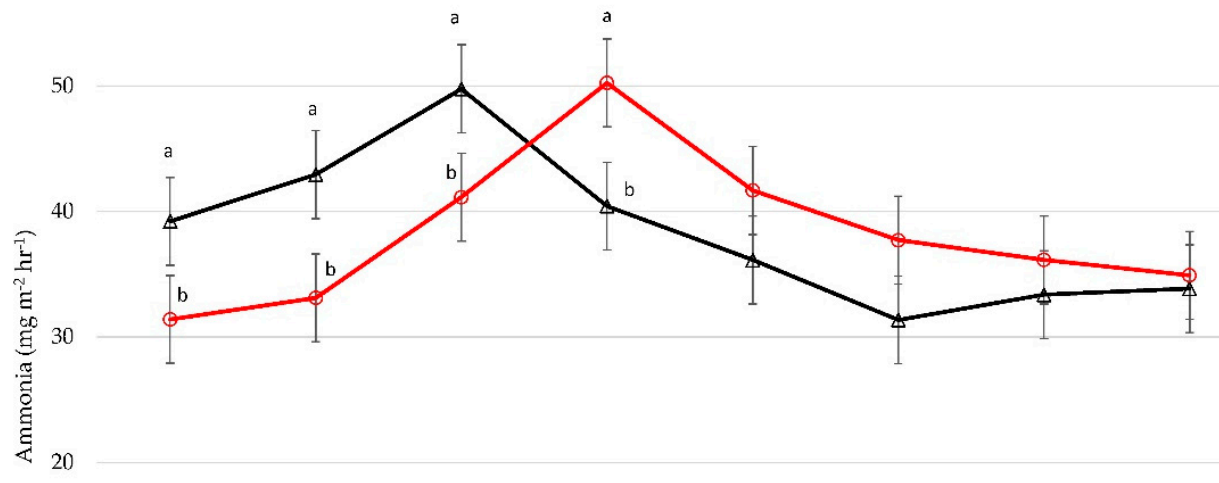

10

0

3

10

14

17

21

24 Day

$\leftarrow 0 \%$ Alum $\neg 5 \%$ Alum

Figure 5. Cont. 
c. Dimethyldisulfide (DMDS) flux over time

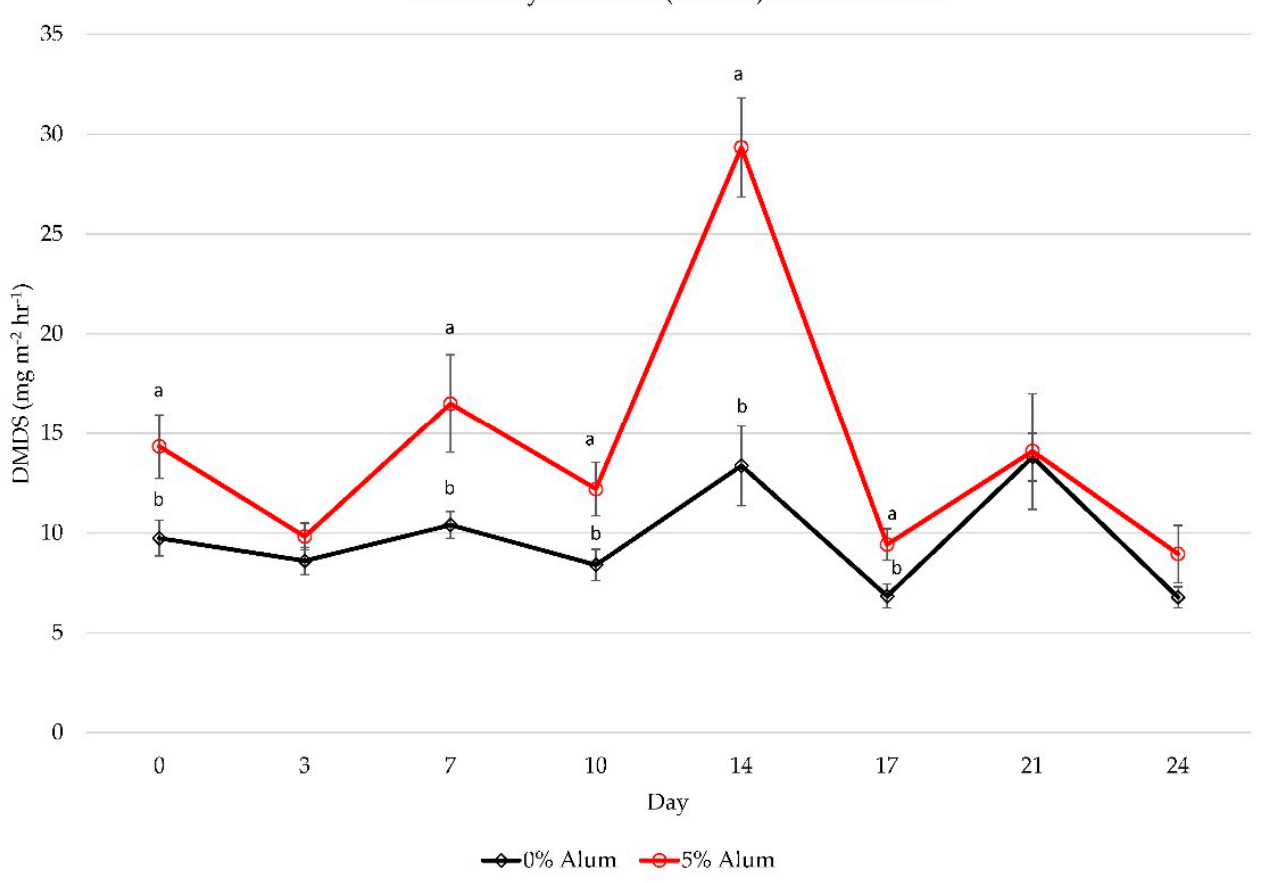

Figure 5. (a) The $\mathrm{pH}$ of the feedlot surface with and without the addition of $5 \%$ alum. The addition of alum significantly lowered $\mathrm{pH}$ for the 24 days of the study. (b). Ammonia flux from feedlot surface treated with $5 \%$ alum and untreated feedlot surface. While $\mathrm{NH}_{3}$ flux was lower for feedlot surface areas treated with $5 \%$ alum for up to 7 days, overall $\mathrm{NH}_{3}$ flux did not differ between the two treatments. The peak $\mathrm{NH}_{3}$ flux was just shifted when $5 \%$ alum was added to the feedlot surface. Different letters indicate significant differences between the treatments at the time point. (c). Dimethyl disulfide (DMDS) flux from the feedlot surface treated with and without $5 \%$ alum differed significantly at five of eight time points in the study, with the pens treated with $5 \%$ alum have significantly greater DMDS flux. Different letters indicate significant differences between the treatments at the time point. For all graphs, different letters indicate significant differences between the treatments at the time point.

Based on the lab-scale study using $0-10 \%$ alum, it appeared that there was little difference between the addition of 5 and 10\% alum to the FSM. Both were able to reduce $\mathrm{pH}$ and $\mathrm{NH}_{3}$ flux from the FSM and retain significantly more ammonium-N in the FSM compared to FSM treated with $0 \%$ alum. Concerns over the increase in sulfur concentration in the FSM as the concentration of alum increased, as well as concern that prolonged exposure to low $\mathrm{pH}$ would irritate the hooves and feet of cattle, led to the use of $5 \%$ alum on the feedlot surface. However, while able to effectively lower the $\mathrm{pH}$ of the feedlot surface, the addition of $5 \%$ alum to the surface was not able to sustain a reduced $\mathrm{NH}_{3}$ flux for longer than 1 week, and overall $\mathrm{NH}_{3}$ emissions were similar between the treated and untreated feedlot surfaces. Analysis of the VOCs demonstrated a significant overall increase in DMDS flux (Figure 5c) for feedlot pen areas treated with $5 \%$ alum $\left(14.3 \pm 0.5 \mathrm{mg} \mathrm{m}^{-2} \mathrm{hr}^{-1}\right)$ compared to areas that did not receive a treatment $\left(9.72 \pm 1.1 \mathrm{mg} \mathrm{m}^{-2} \mathrm{hr}^{-1}\right)$. Dimethyltrisulfide flux was similar $(p=0.36)$ for pen areas treated with $5 \%$ alum $\left(0.33 \pm 0.06 \mathrm{mg} \mathrm{m}^{-2} \mathrm{hr}^{-1}\right)$ and untreated areas $\left(0.27 \pm 0.05 \mathrm{mg} \mathrm{m}^{-2} \mathrm{hr}^{-1}\right)$.

A second feedlot surface study was conducted using $10 \%$ alum treatment to determine if the higher concentration of alum could suppress $\mathrm{NH}_{3}$ emissions for longer than 7 days. There was concern that too much alum would lower the $\mathrm{pH}$ of the feedlot surface below 5.5 and cause irritation to cattle's hooves or hides, so a preliminary study was conducted using $10 \%$ alum in one pen under the supervision of the USMARC herd veterinarian to determine if any hoof irritation was present. Feedlot surface material samples were collected from the pen surface, and $\mathrm{pH}$ was measured daily. The cattle were also observed daily by the 
veterinarian for any signs of irritation. Once the pen $\mathrm{pH}$ was above 7 , the observations ceased. No irritation was observed on the hide or hooves of any animal in the pen; thus, it was determined that $10 \%$ alum would be safe to administer to the feedlot pens of beef cattle.

Consistent with all the previous studies conducted by our lab, the addition of $10 \%$ alum to the feedlot surface significantly reduced the $\mathrm{pH}$ of the feedlot surface material compared to untreated areas of the pen (Figure 6a).

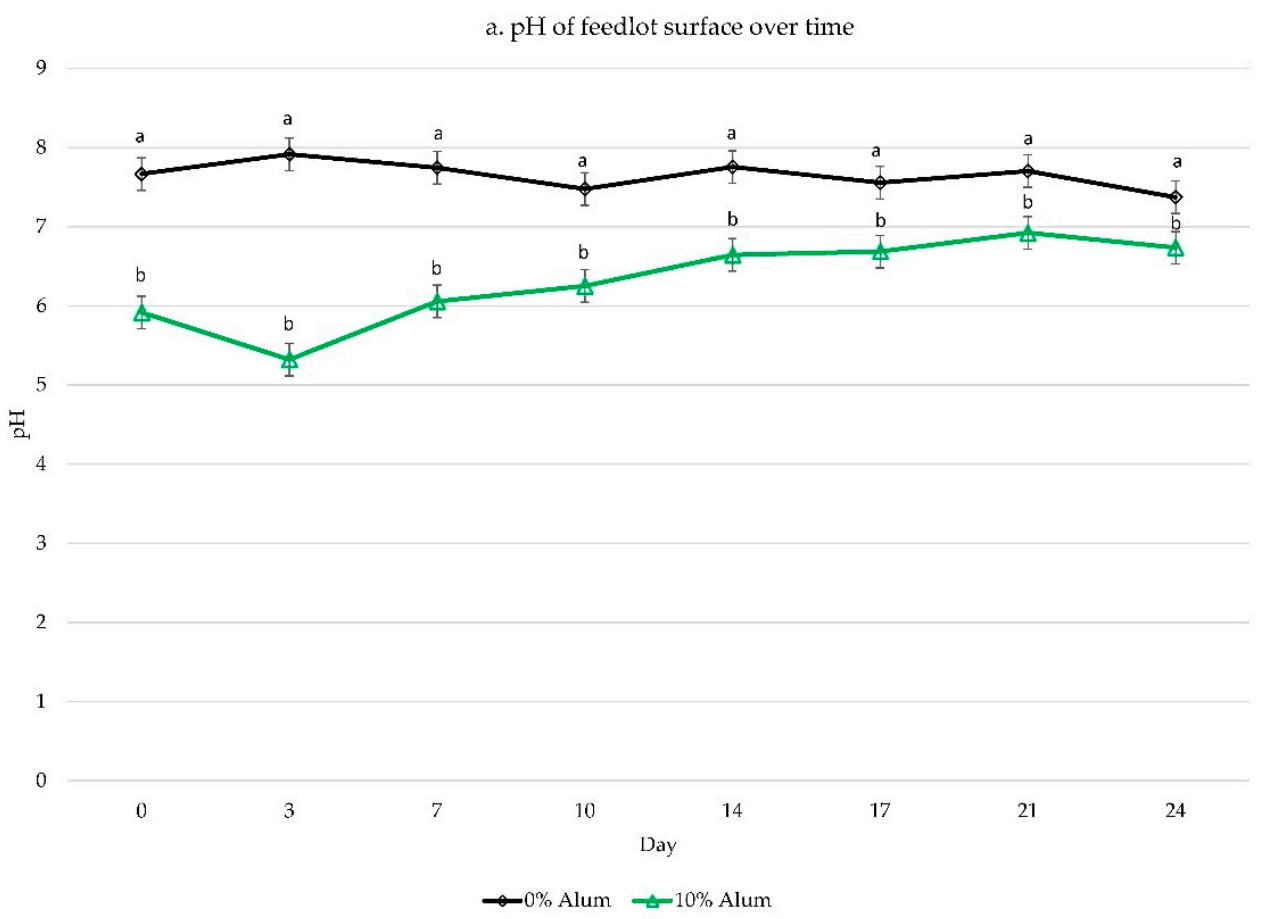

b. Ammonia flux over time

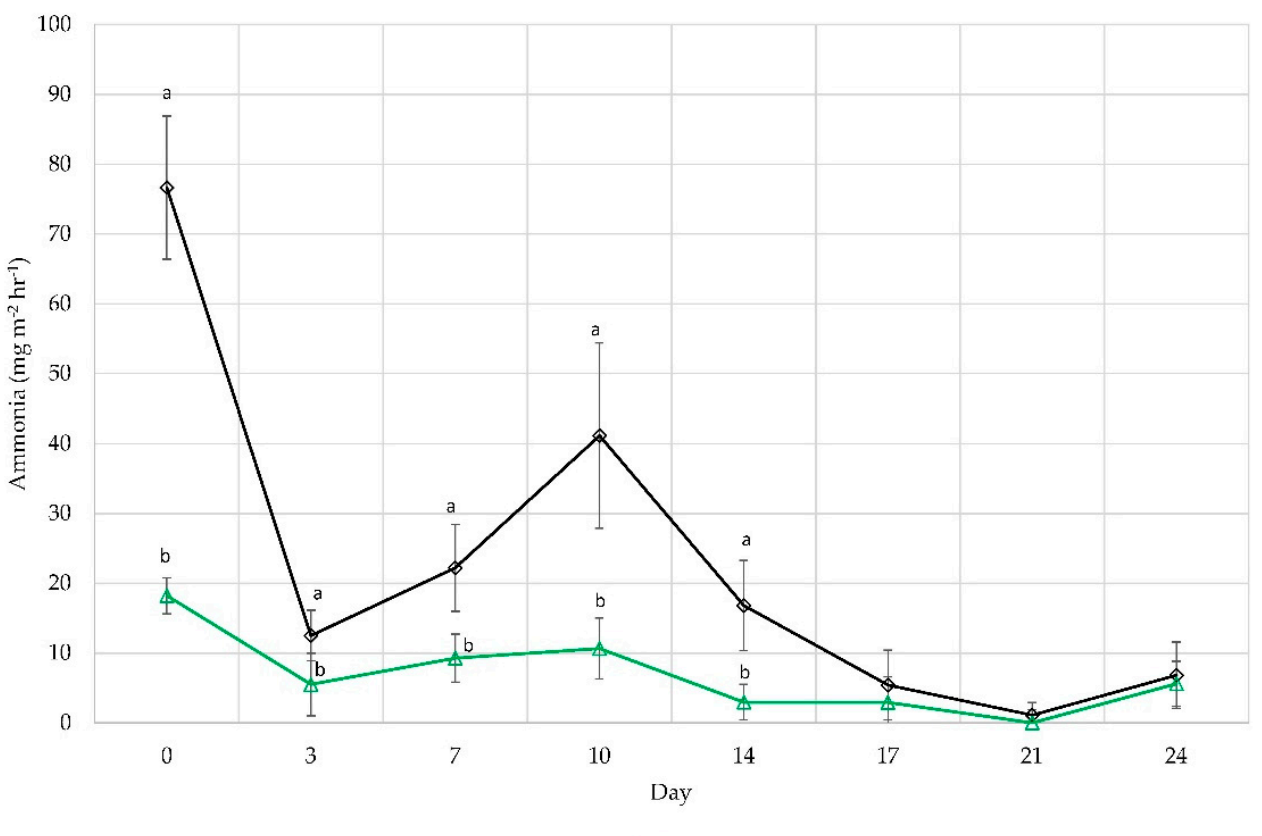

$\neg 0 \%$ Alum $\triangle 10 \%$ Alum

Figure 6. Cont. 


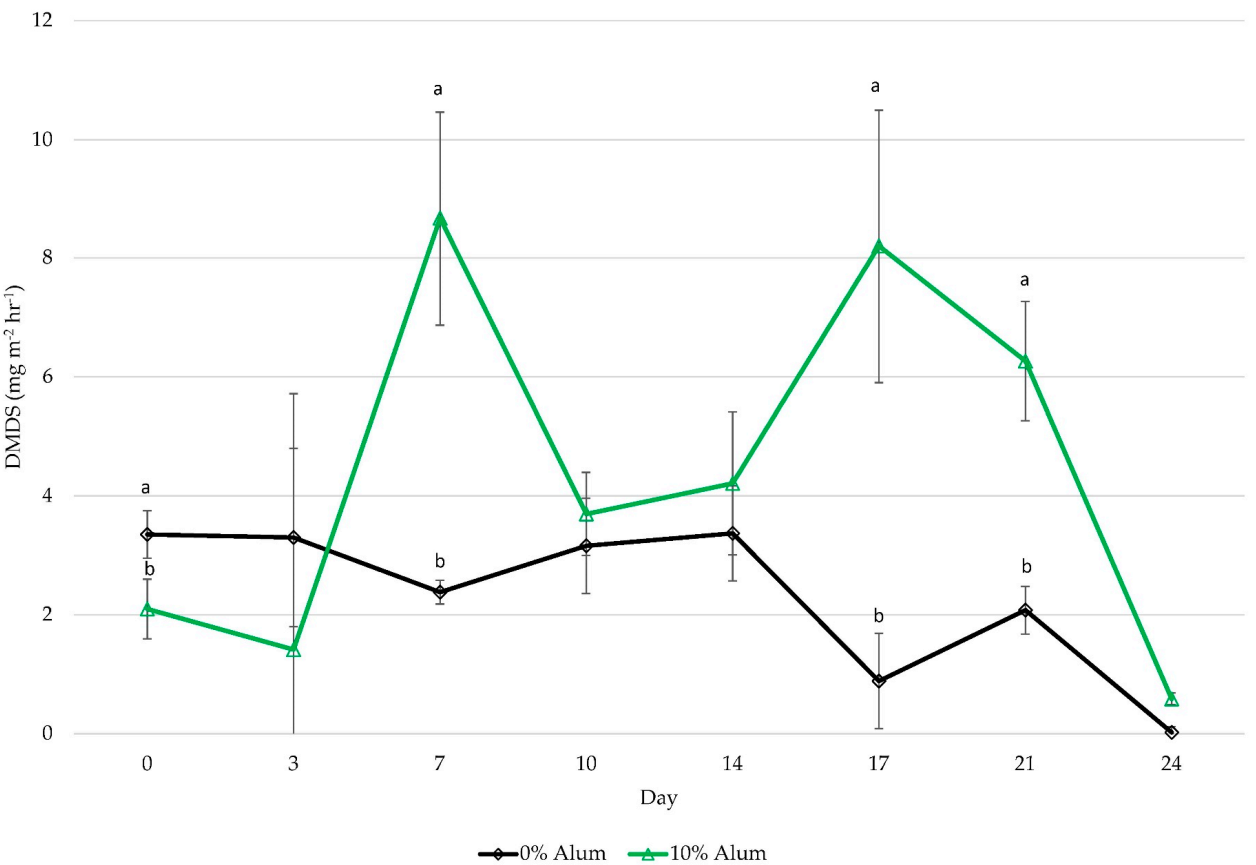

Figure 6. (a) The addition of $10 \%$ alum to the feedlot surface of beef cattle pens effectively lowered pen surface $\mathrm{pH}$ for the 24-day duration of the study compared to pens that did not receive an alum treatment. (b) Addition of $10 \%$ alum to the feedlot surface significantly reduced $\mathrm{NH}_{3}$ flux for up to 14 days following application compared to untreated feedlot surface areas. Different letters indicate significant differences between the treatments at the time point. (c). Dimethyl disulfide (DMDS) flux was highly variable during the study but was greater for feedlot surface areas treated with $10 \%$ alum at days $0,7,17$, and 21 compared to untreated feedlot surface areas. For all graphs, different letters indicate significant differences between the treatments at the time point.

The addition of $10 \%$ alum to the feedlot surface significantly reduced $\mathrm{NH}_{3}$ flux for up to 14 days following application compared to untreated feedlot surfaces (Figure $6 b$ ). Ammonia flux for both treatments decreased over time and emissions were quite low for both treatments from day 17 until the end of the 24-day study, indicating that $\mathrm{N}$ substrate on the feedlot surface was depleted. Therefore, it is unknown if the addition of $10 \%$ alum would continue to suppress $\mathrm{NH}_{3}$ emissions if cattle were present and continually adding new $\mathrm{N}$ substrate.

Dimethyltrisulfide flux was very small and not significantly different $(p=0.10)$ between the treated $\left(0.02 \pm 0.01 \mathrm{mg} \mathrm{m}^{-2} \mathrm{hr}^{-1}\right)$ and untreated areas $\left(0.01 \pm 0.01 \mathrm{mg} \mathrm{m}^{-2} \mathrm{hr}^{-1}\right)$ of the pen. Dimethyldisulfide flux was highly variable throughout the study but was greater at days $0,7,17$, and 21 for pen surface areas treated with $10 \%$ alum compared to pen surface areas that did not receive an alum treatment. This was, again, consistent with previous studies that demonstrated increased sulfide flux when alum was added to the feedlot surface.

Total $\mathrm{N}\left(\mathrm{g} \mathrm{kg}^{-1}\right)$ was higher in the FSM treated with $10 \%$ alum compared to FSM that did not receive an alum treatment (Table 4). However, individual $\mathrm{N}$ components were similar between the FSM from the treated and untreated areas of the feedlot pen. Consistent with previous studies, the sulfur content of the FSM was significantly greater when alum was applied to the feedlot surface. 
Table 4. Comparison of the nutrient composition of cattle feedlot surface areas treated with $10 \%$ aluminum sulfate (alum) and no treatment.

\begin{tabular}{|c|c|c|c|c|}
\hline Nutrient & Initial FSM & 0\% Alum & $10 \%$ Alum & $p$-Value \\
\hline Dry matter, \% & $44.9 \pm 1.0$ & $51.4 \pm 2.0$ & $57.5 \pm 1.5$ & 0.01 \\
\hline Total N, $\mathrm{g} \mathrm{kg}^{-1}$ & $19.8 \pm 1.3$ & $18.1 \pm 0.5$ & $19.7 \pm 0.4$ & 0.01 \\
\hline Organic-N, g kg ${ }^{-1}$ & $17.4 \pm 1.3$ & $17.6 \pm 0.4$ & $17.8 \pm 0.4$ & 0.68 \\
\hline Ammonium-N, $\mathrm{g} \mathrm{kg}^{-1}$ & $2.4 \pm 0.3$ & $0.9 \pm 0.3$ & $3.1 \pm 1.1$ & 0.08 \\
\hline Nitrate-N, $\mathrm{g} \mathrm{kg}^{-1}$ & $0.01 \pm 0.0$ & $0.01 \pm 0.0$ & $0.01 \pm 0.0$ & - \\
\hline Total Sulfur, $\mathrm{g} \mathrm{kg}^{-1}$ & $6.7 \pm 0.9$ & $6.5 \pm 0.2 \mathrm{~b}$ & $16.8 \pm 0.6 \mathrm{a}$ & $>0.01$ \\
\hline
\end{tabular}

All nutrient compositions, except dry matter content, were on a dry-matter basis. Different letters within a row indicate significant difference among treatments at $p<0.05$.

Ammonia volatilization from the feedlot surface depends on several variables including $\mathrm{pH}$, temperature, and moisture content. When $\mathrm{pH}$ is above 8 , a large percentage of inorganic nitrogen $(\mathrm{N})$ is in the $\mathrm{NH}_{3}$ form and can be easily volatilized. When $\mathrm{pH}$ is lowered, $\mathrm{N}$ is converted to the nonvolatile ammonium form which increases $\mathrm{N}$ in the manure thereby improving the fertilizer value. Alum can reduce the $\mathrm{pH}$ of feedlot surface material due to the hydrolysis of aluminum [48]. The results of the four studies were consistent in that the addition of alum to the FSM or beef feedlot did lower the $\mathrm{pH}$ for at least 7 days. While the addition of alum at concentrations even as low as $2.5 \%\left(\mathrm{~g} \mathrm{~g}^{-1}\right)$, can effectively lower the $\mathrm{pH}$ of the feedlot surface material, $\mathrm{NH}_{3}$ flux was only lowered for up to 14 days when alum was applied. This indicates that the environmental conditions in a feedlot pen are more complex than in a controlled environment and that other factors beyond $\mathrm{pH}$ such as temperature, moisture, and even bacterial metabolism of $\mathrm{N}$ sources may be contributing to the volatilization of $\mathrm{NH}_{3}$ from the feedlot surface. It should be noted that the design of the studies did not provide fresh N sources to the FSM as would occur on a feedlot surface with cattle present. Therefore, after 14 days the $\mathrm{N}$ substate that was present in the FSM was likely volatilized or used by microbes for biological processes. A study in which fresh $\mathrm{N}$ sources could be applied would help determine if the alum becomes ineffective in lowering $\mathrm{NH}_{3}$ emissions after 14 days, or if the decrease in overall $\mathrm{NH}_{3}$ emissions due to loss of substrate made it impossible to detect differences in $\mathrm{NH}_{3}$ volatilization from the FSM.

One way to maintain the lower $\mathrm{pH}$ would be more frequent additions of alum to the feedlot surface. It was hypothesized that weekly, smaller doses of alum to the FSM would maintain a consistently lower $\mathrm{pH}$ over a longer period compared to one initial dose. In turn, this would continue to suppress $\mathrm{NH}_{3}$ emissions beyond the 7 days that was observed in the lab-scale study. However, the second lab-scale study demonstrated that this was not the case. Another alternative that was not evaluated would be to apply an initial dose of 5 or $10 \%$ alum and then add smaller increments on a weekly or biweekly basis to maintain adequate alum concentration to inhibit $\mathrm{NH}_{3}$ emissions. However, this could become expensive and labor-intensive for feedlot producers.

One concern for beef feedlot producers looking to lower the $\mathrm{NH}_{3}$ emissions from their operation is the cost of the mitigation. The dry aluminum sulfate used in these studies was purchased in $22.7 \mathrm{~kg}$ bags at a cost of USD 16.50-17.00 per bag. When applied at a rate of $10 \%$ to the top $5 \mathrm{~cm}$ of the feedlot surface the cost would be USD $8.03 / \mathrm{m}^{2}$ (USD $0.75 / \mathrm{ft}^{2}$ ). This would not be a cost-effective treatment for most producers who allow $14-23 \mathrm{~m}^{2}$ per animal [51]. However, research has demonstrated that spatial variation exists in feedlot pens, which contributes to differences in odor and greenhouse gas emissions [34,35]. By identifying the locations in the pen that contribute the most to $\mathrm{NH}_{3}$ emissions, perhaps alum could be applied to the specific areas of the pen, instead of the entire pen, making it a more cost-effective treatment for producers.

The biggest concern with using alum on the cattle feedlot surface appears to be in the increase in sulfide emissions in the form of $\mathrm{H}_{2} \mathrm{~S}$ and other reduced sulfide compounds. The primary source of this $\mathrm{H}_{2} \mathrm{~S}$ emission appears to be the additional sulfur substrate added to the FSM with the addition of alum. Hydrogen sulfide emission contributes to odors 
from livestock facilities and exposure to $\mathrm{H}_{2} \mathrm{~S}$ can be harmful or even fatal to humans and livestock [51]. Hydrogen sulfide flux is produced as a result of sulfate reduction obligate anaerobic bacteria [52]. A low $\mathrm{pH}(<7.0)$ favors $\mathrm{H}_{2} \mathrm{~S}$ production [53]. Previous research has demonstrated an increase in $\mathrm{H}_{2} \mathrm{~S}$ concentrations by $285 \%$ when the $\mathrm{pH}$ of stored liquid dairy manure was decreased from 7.32 to 6.82 [54]. Reducing the $\mathrm{pH}$ of wastewater sewage to 4.5 increased $\mathrm{H}_{2} \mathrm{~S}$ production [55]. Therefore, the low $\mathrm{pH}$ created by the application of alum to inhibit $\mathrm{NH}_{3}$ volatilization may also be contributing to the release of $\mathrm{H}_{2} \mathrm{~S}$ and other sulfide emissions. Similar results were reported when aluminum sulfate was added to liquid swine manure [56] and suggested that aluminum chloride may be a suitable substitute for alum to lower $\mathrm{pH}$ and inhibit $\mathrm{NH}_{3}$ volatilization without increasing sulfide emissions.

\section{Conclusions}

The addition of $10 \%$ alum effectively lowered the pH of FSM for nearly a month, but $\mathrm{NH}_{3}$ emissions were only significantly lower for 7-14 days. Total $\mathrm{N}$ content was higher in the FSM that contained alum, which may improve the fertilizer value of the manure. However, these benefits are offset by the significantly higher sulfide emissions that result from lowering the $\mathrm{pH}$ and adding sulfurs substrate to the FSM, making alum an unattractive feedlot surface amendment for cattle producers. Future studies should examine aluminum chloride, include a method of adding additional $\mathrm{N}$ substrate to better evaluate the long-term effectiveness of the feedlot surface amendment, and also examine the effects of adding small portions of the amendment at scheduled intervals to maintain the effectiveness of the amendment.

Author Contributions: Conceptualization, M.J.S. and B.W.; methodology, M.J.S. and B.W.; software, M.J.S. and B.W.; validation, M.J.S. and B.W.; formal analysis, M.J.S. and B.W.; investigation, M.J.S. and B.W.; resources, M.J.S. and B.W.; data curation, M.J.S. and B.W.; writing-original draft preparation, M.J.S.; writing-review and editing, M.J.S. and B.W.; visualization, M.J.S. and B.W.; supervision, M.J.S.; project administration, M.J.S. and B.W.; funding acquisition, M.J.S. and B.W. All authors have read and agreed to the published version of the manuscript.

Funding: This research received no external funding.

Institutional Review Board Statement: The animal study protocol was approved by the Institutional Animal Care and Use Committee of the U.S. Meat Animal Research Center (Experiment Number: 130.0. Approved 14 May 2020).

Informed Consent Statement: Not applicable.

Data Availability Statement: The data presented in this study are available on request from the corresponding author.

Acknowledgments: The authors wish to thank USMARC technicians Alan Kruger and Todd Boman and USMARC Summer Interns Zach Duncan and Nathan Long for help with data collection and lab analysis. The authors also wish to acknowledge the employees of the USMARC Area 25 Cattle Operations and Feedlot Operations for their assistance with the study. USDA is an equal opportunity provider and employer. The mention of trade names of commercial products in this article is solely for the purpose of providing specific information and does not imply recommendation or endorsement by the USDA.

Conflicts of Interest: The authors declare no conflict of interest.

\section{References}

1. Mackie, R.I.; Stroot, P.G.; Varel, V.H. Biochemical identification and biological origin of key odor components in livestock waste. J. Anim. Sci. 1998, 76, 1331-1342. [CrossRef] [PubMed]

2. Miller, D.N.; Varel, V.H. In vitro study of the biochemical origin and production limits of odorous compounds in cattle feedlots. J. Anim. Sci. 2001, 79, 2949-2956. [CrossRef] [PubMed]

3. Miller, D.N.; Berry, E.D. Cattle feedlot soil moisture and manure content: I. Impacts on greenhouse gases, odor compounds, nitrogen losses, and dust. J. Environ. Qual. 2005, 34, 644-655. [CrossRef] [PubMed]

4. Rappert, S.; Muller, R. Odor compounds in waste gas emission form agricultural operation and food industries. Waste Manag. 2005, 25, 887-907. [CrossRef] 
5. Trabue, S.; Kerr, B.; Bearson, B.; Ziemer, C. Swine odor analyzed by odor panels and chemical techniques. J. Environ. Qual. 2011, 40, 1510-1520. [CrossRef]

6. Trabue, S.; Scoggin, K.; McConnell, L.; Maghirang, R.; Razote, E.; Hatfield, J. Identifying and tracking key odorants from cattle feedlots. Atmos. Environ. 2011, 45, 4243-4251. [CrossRef]

7. Preece, S.L.M.; Casey, K.D.; Auvermann, B.W. Hydrogen Sulfide Emissions from Open/Dry-Lot Cattle-Feeding Operations, Texas Agri-Life Extension, E-620. 2012. Available online: https://agrilifeextension.tamu.edu/library/ranching/hydrogen-sulfideemissions-from-open-dry-lot-cattle-feeding-operations / (accessed on 20 December 2021).

8. National Research Council (US) Committee on Acute Exposure Guideline Levels. Acute Exposure Guideline Levels for Selected Airborne Chemicals; National Academies Press: Washington, DC, USA, 2008; Volume 6. Available online: https://www.ncbi.nlm. nih.gov/books/NBK207883/ (accessed on 19 January 2022).

9. Fazzalari, F.A. (Ed.) Compilation of Odor and Taste Threshold Data; ASTM Data Series DS 48A; ASTM Data: Philadelphia, PA, USA, 1978.

10. Buttery, B.G.; Turnbaugh, J.G.; Ling, L.C. Contribution of volatiles to rice aroma. J. Agric. Food Chem. 1988, 36, 1006-1009. [CrossRef]

11. O'Neill, D.H.; Phillips, V.R. A review of the control of odour nuisance from livestock buildings: Part 3, properties of the odorous substances which have been identified in livestock waste or in the air around them. J. Agric. Eng. Res. 1992, 53, 23-50. [CrossRef]

12. Moulders, E.J. The odour of white bread IV. Quantitative determination of constituents in the vapour and their odour values. Z Lesensm. Unters. Forsch. 1973, 151, 310-317.

13. Guadagni, G.; Buttery, R.G.; Okano, S. Odour thresholds of some organic compounds associated with food flavours. J. Sci. Food Agric. 1963, 14, 761-765. [CrossRef]

14. Buttery, R.G.; Teranishi, R.; Flath, R.A.; Ling, L.C. Identification of additional tomato paste volatiles. J. Agric. Food Chem. 1990, 38, 792-795. [CrossRef]

15. Buttery, B.G.; Guadagni, D.; Ling, L.; Seifert, R.; Lipton, W. Additional volatile compounds of cabbage, broccoli, and cauliflower. J. Agric. Food Chem. 1976, 24, 829-832. [CrossRef]

16. Stowell, R. Ammonia Loss and Emission Reporting: Considerations for Cattle Operations. UNL BeefWatch, 1 February 2018 Available online: http:/ / newsroom.unl.edu/announce/beef/7498/42942 (accessed on 20 December 2021).

17. Bierman, S.; Klopfenstein, T.J.; Stock, R.; Shain, D. Evaluation of Nitrogen, Phosphorus, and Organic Matter Balance in the Feedlot as Affected by Nutrition; Beef Cattle Report MP66-A; University of Nebraska-Lincoln: Lincoln, NE, USA, 1996 ; pp. 74-76.

18. Van Horn, H.H.; Newton, G.L.; Kunkle, W.E. Ruminant nutrition from an environmental perspective: Factors affecting whole-farm nutrient balance. J. Anim. Sci. 1996, 74, 3082-3102. [CrossRef]

19. Hausinger, R.P. Metabolic versatility of prokaryotes for urea deposition. J. Bacteriol. 2004, 186, 2520-2522. [CrossRef] [PubMed]

20. Bierman, S.; Erickson, G.E.; Klopfenstein, T.J.; Stock, R.A.; Shain, D.H. Evaluation of nitrogen and organic matter balance in the feedlot as affected by level and source of dietary fiber. J. Anim. Sci. 1999, 77, 1645-1653. [CrossRef]

21. Erickson, G.; Klopfenstein, T. Managing N inputs and the effect on N volatilization following excretion in open-dirt feedlots in Nebraska. Nitrogen in the environment. Sci. World J. 2001, 52, 830. [CrossRef]

22. Todd, R.; Cole, N.; Clark, R.; Flesch, T.; Harper, L.; Baek, B. Ammonia emissions form beef cattle feedyard on the southern High Plains. Atmos. Environ. 2008, 42, 6769-6805. [CrossRef]

23. Homolka, M.N.; Erickson, G.E.; Koelsch, R.K. Predicting nitrogen and phosphorus balance in beef open lots. Appl. Ani. Sci. 2021, 37, 641-653. [CrossRef]

24. Hartung, J.; Phillips, V.R. Control of gaseous emissions from livestock buildings and manure stores. J. Agric. Eng. Res. 1994, 57, 173-189. [CrossRef]

25. Rhoades, M.; Parker, D.; Cole, N.; Todd, R.; Caraway, E.; Auvermann, B.; Topliff, D.; Schuster, G. Continuous ammonia emission measurements from a commercial beef feedyard in Texas. Trans. ASABE 2010, 53, 1823-1831. [CrossRef]

26. Shi, Y.; Parker, D.B.; Cole, N.A.; Auvermann, B.W.; Mehlhorn, J.E. Surface amendments to minimize ammonia emissions from beef cattle feedlots. Trans. ASABE 2001, 44, 677-682. [CrossRef]

27. Varel, V.H.; Wells, J.E.; Miller, D.N. Combination of urease inhibitor and plant essential oil to control coliform bacteria, odour production and ammonia loss from cattle waste. J. Appl. Microbiol. 2007, 102, 472-477. [CrossRef] [PubMed]

28. Cole, N.A.; Todd, R.W.; Parker, D.B. Use of fat and zeolite to reduce ammonia emissions from beef cattle feedyards. In Proceedings of the International Symposium on Air Quality and Waste Management for Agriculture, Broomfield, CO, USA, 16-19 September 2007.

29. Moore, P.A., Jr.; Daniel, T.C.; Edwards, D.R.; Miller, D.N. Effect of chemical amendments on ammonia volatilization from poultry litter. J. Environ. Qual. 1995, 24, 293-300. [CrossRef]

30. Moore, P.A., Jr.; Daniel, T.C.; Edwards, D.R. Reducing phosphorus runoff and inhibiting ammonia loss from poultry manure with aluminum sulfate. J. Environ. Qual. 2000, 29, 37-49. [CrossRef]

31. Moore, P.A.; Edwards, D.R. Long-term effects of poultry litter, alum-treated litter, and ammonium nitrate on phosphorus availability in soils. J. Environ. Qual. 2007, 36, 163-174. [CrossRef]

32. Warren, J.G.; Phillips, S.B.; Mullins, G.L.; Keahey, D.; Penn, C.J. Environmental and production consequences of using alumamended poultry litter as a nutrient source for corn. J. Environ. Qual. 2006, 35, 172-183. [CrossRef]

33. Spiehs, M.J.; Woodbury, B.L.; Parker, D.B. Ammonia, hydrogen sulfide, and greenhouse gas emissions from lab-scaled manure bedpacks with and without aluminum sulfate additions. Environments 2019, 6, 108. [CrossRef] 
34. Woodbury, B.L.; Gilley, J.E.; Parker, D.B.; Stromer, B.S. Greenhouse gas emissions from beef feedlot surface materials as affected by diet, moisture, temperature, and time. Trans. ASABE 2018, 61, 571-582. [CrossRef]

35. Woodbury, B.L.; Gilley, J.E.; Parker, D.B.; Marx, D.B.; Eigenberg, R.A. VOC emissions from beef feedlot pen surfaces as affected by within-pen location, moisture, and temperature. Biosystem. Engng. 2015, 134, 31-41. [CrossRef]

36. Parker, D.B.; Caraway, E.A.; Rhoades, M.B.; Cole, N.A.; Todd, R.W.; Casey, K.D. Effect of wind tunnel air velocity on VOC flux from standard solutions and CAFO manure/wastewater. Trans ASABE 2010, 53, 831-845. [CrossRef]

37. Watson, M.A.; Wolf, A.; Wolf, N. Total Nitrogen. In Recommended Methods of Manure Analysis; Publication No. A3769; University of Wisconsin Cooperative Extension: Madison, WI, USA, 2003; pp. 18-24.

38. Wolf, A.; Watson, M.; Wolf, N. Digestion and dissolution methods for P, K, Ca, Mg, and trace elements. In Recommended Methods of Manure Analysis; Publication No. A3769; University of Wisconsin Cooperative Extension: Madison, WI, USA, 2003 ; pp. 30-38.

39. Mielke, L.N.; Swanson, N.P.; McCalla, T.M. Soil profile conditions of cattle feedlots. J. Environ. Qual. 1974, 3, 14-17. [CrossRef]

40. Miller, J.J.; Curtis, T.; Larney, F.J.; McAllister, T.A.; Olson, B.M. Physical and chemical properties of feedlot pen surface located on moderately coarse- and moderately fine-textured soils in Southern Alberta. J. Environ. Qual. 2008, 37, 1589-1598. [CrossRef] [PubMed]

41. Parkin, T.B.; Venterea, R.T. USDA-ARS GRACEnet Project Protocols, Chapter 3. Chamber-Based Trace Gas Flux Measurements4; Follett, R.F., Ed.; Sampling Protocols: Beltsville, MD, USA, 2010; pp. 1-39. Available online: http:/ /www.ars.usda.gov/SP2UserFiles/ Program/212/Chapter\%203.\%20GRACEnet\%20Trace\%20Gas\%20Sampling\%20Protocols.pdf (accessed on 26 January 2022).

42. Miller, D.N.; Woodbury, B.L. A solid-phase microextraction chamber method for analysis of feces and manures volatiles. J. Environ. Qual. 2006, 35, 2383-2394. [CrossRef]

43. Woodbury, B.L.; Miller, D.N.; Eigenberg, R.A.; Nienaber, J.A. An inexpensive laboratory and field chamber for manure volatile gas flux analysis. Trans. ASABE 2006, 49,767-772. [CrossRef]

44. Spiehs, M.J. Lab-scale model to evaluate odor and gas concentrations emitted by deep bedded pack manure. J. Visualized Expt. 2018, 137, e57332. [CrossRef] [PubMed]

45. Parker, D.B.; Ham, J.; Woodbury, B.; Cai, L.; Spiehs, M.; Rhoades, M.; Trabue, S.; Casey, K.D.; Todd, R.; Cole, N.A. Standardization of flux chamber and wind tunnel flux measurements for quantifying volatile organic compound and ammonia emissions from area sources at animal feeding operations. Atmos. Environ. 2013, 66, 72-83. [CrossRef]

46. Parker, D.B.; Gilley, J.; Woodbury, B.; Kim, K.H.; Bartelt-Hunt, S.; Galvin, G. Odorous VOC emission following land application of swine manure slurry. Atmos. Environ. 2013, 66, 91-100. [CrossRef]

47. SAS. SAS 9.4; SAS Institute Inc.: Cary, NC, USA, 2016.

48. Smith, D.R.; Moore, P.A., Jr.; Griffis, C.L.; Daniel, T.C.; Edwards, D.R.; Boothe, D.L. Effects of alum and aluminum chloride on phosphorus runoff from swine manure. J. Environ. Qual. 2001, 30, 992-998. [CrossRef]

49. Ueki, A. Sulfate-reduction in anaerobic digestion of animal waste. J. Gen. Appl. Microbiol. 1986, 32, 111-123. [CrossRef]

50. Choi, I.H.; Moore, P.A., Jr. Effects of liquid aluminum chloride additions to poultry litter on broiler performance, ammonia emissions, soluble phosphorus, total volatile fatty acids, and nitrogen content of litter. Poultry Sci. 2008, 87, 1955-1963. [CrossRef]

51. Euken, R.; Doran, B.; Clark, C.; Shouse, S.; Ellis, S.; Loy, D.; Schultz, L. Beef Feedlot Systems Manual; PM 1867; Iowa State University Extension and Outreach: Ames, IA, USA, 2015.

52. Hooser, S.B.; Van Alstine, W.; Kiupel, M.; Sojka, J. Acute pit gas (hydrogen sulfide) poisoning in confinement cattle. J. Vet. Diag. Invest. 2000, 12, 272-275. [CrossRef] [PubMed]

53. Zang, B.; Shuyan, L.; Frederick, M.C.; Guoxue, L.; Zhang, D.; Yangyang, L. Control of dimethyl sulfide and dimethyl disulfide odors during pig manure composting using nitrogen amendment. Bioresour. Technol. 2017, 224, 419-427. [CrossRef] [PubMed]

54. Linderholm, A.L.; Findleton, C.L.; Kumar, G.; Hong, Y.; Bisson, L.F. Identification of genes affecting hydrogen sulfide formation in Saccharomyces cerevisiae. Appl. Environ. Microb. 2008, 74, 1418-1427. [CrossRef] [PubMed]

55. Andriamanohiarisoamanana, F.J.; Sakamoto, Y.; Yamashiro, T.; Yasui, S.; Iwasaki, M.; Ihara, I.; Umetsu, K. Effects of handling parameters on hydrogen sulfide emission from stored dairy manure. J. Environ. Manag. 2015, 154, 110-116. [CrossRef] [PubMed]

56. Yongsiri, C.; Vollertsen, J.; Hvitved-Jacobsen, T. Effect of temperature on air-water transfer of hydrogen sulfide. J. Environ. Eng. 2004, 130, 104-109. [CrossRef] 